\title{
Vitamin $D 3$ protects against $A \beta$ peptide cytotoxicity in differentiated human neuroblastoma SH- SY5Y cells: a role for S1P1/p38MAPK/ATF4 axis
}

Federica Pierucci ${ }^{1,2}$, Mercedes Garcia-Gil ${ }^{3,4}$, Alessia Frati ${ }^{1}$, Francesca Bini ${ }^{1}$, Maria Martinesi ${ }^{1}$, Eleonora Vannini ${ }^{5}$, Marco Mainardi ${ }^{5}$, Federico Luzzati $^{6}$, Paolo Peretto $^{6}$, Matteo Caleo $^{5}$, and Elisabetta Meacci $^{1,2 *}$

${ }^{1}$ Department of Experimental and Clinical Biomedical Sciences "Mario Serio", Molecular and Applied Biology Research Unit, University of Florence, Viale GB Morgagni 50, 5134 Firenze (Italy)

2 Interuniversitary Miology Institutes (Italy)

${ }^{3}$ Department of Biology, University of Pisa, Via San Zeno, 31, 56127 Pisa (Italy)

${ }^{4}$ Interdepartmental Research Center Nutrafood "Nutraceuticals and Food for Health", University of Pisa, Via del Borghetto 80, 56124 Pisa (Italy)

5 Neuroscience Institute, CNR, 56124 Pisa (Italy)

6 Department of Life Sciences and Systems Biology, University of Turin, Neuroscience Institute Cavalier Ottolenghi, Via Verdi 8, 10124 Turin (Italy)

\section{Highlights}

$1,25(\mathrm{OH})_{2} \mathrm{D}_{3}$ promotes the increase of the pro-survival factor S1P and the decrease of the pro-apoptotic ceramide in SH-SY5Y differentiated cells

- The neuroprotective effect of $1,25(\mathrm{OH})_{2} \mathrm{D}_{3}$ against the $\beta$-amyloid-induced toxicity involves the receptor subtype S1P1 signaling

- Downstream signaling of S1P1 in $1,25(\mathrm{OH})_{2} \mathrm{D}_{3}$-induced neuroprotection involves p38MAPK/ER stress-induced transcription factor ATF4 axis

$1,25(\mathrm{OH})_{2} \mathrm{D}_{3}$-analogue $\mathrm{ZK} 191784$ mimics hormone action in neuroprotection against $\beta$-amyloidinduced toxicity

Keywords: Vitamin D; sphingosine 1-phosphate; ceramide; ER stress; $\beta$-amyloid peptide;

SH-SY5Y cells; ATF4; p38 MAPK

DISCLOSURE STATEMENT: The authors have nothing to disclose.

*Address for reprint requests and other correspondence:

Prof. Elisabetta Meacci

University of Florence

Department of Experimental and Clinical Biomedical Sciences "Mario Serio"

Research unit of Molecular and Applied Biology Viale GB Morgagni 50 - 50134 Firenze (Italy)

tel+390552751231 elisabetta.meacci@unifi.it 


\section{Abstract}

Besides its classical function of bone metabolism regulation, 1 1 , 25-dihydroxyvitamin $\mathrm{D} 3\left(1,25(\mathrm{OH})_{2} \mathrm{D}_{3}\right)$, acts on a variety of tissues including the nervous system, where the hormone plays an important role as neuroprotective, antiproliferating and differentiating agent. Sphingolipids are bioactive lipids that play critical and complex roles in regulating cell fate. In the present paper we have investigated whether sphingolipids are involved in the protective action of $1,25(\mathrm{OH})_{2} \mathrm{D}_{3}$. We have found that $1,25(\mathrm{OH})_{2} \mathrm{D}_{3}$ prevents amyloid- $\beta$ peptide $(A \beta(1-42))$ cytotoxicity both in differentiated SH-SY5Y human neuroblastoma cells and in vivo. In differentiated SH-SY5Y cells, A $\beta(1-42)$ strongly reduces the sphingosine-1-phosphate (S1P)/ceramide (Cer) ratio while $1,25(\mathrm{OH})_{2} \mathrm{D}_{3}$ partially reverts this effect. $1,25(\mathrm{OH})_{2} \mathrm{D}_{3}$ reverts also the $\mathrm{A} \beta(1-42)$-induced reduction of sphingosine kinase activity. We have also studied the crosstalk between $1,25(\mathrm{OH})_{2} \mathrm{D}_{3}$ and S1P signaling pathways downstream to the activation of S1P receptor subtype S1P1. Notably, we found that $1,25(\mathrm{OH})_{2} \mathrm{D}_{3}$ prevents the reduction of S1P1 expression promoted by $\mathrm{A} \beta(1-42)$ and thereby it modulates the downstream signaling leading to ER stress damage (p38MAPK/ATF4). Similar effects were observed by using ZK191784. In addition, chronic treatment with $1,25(\mathrm{OH})_{2} \mathrm{D}_{3}$ protects from aggregated $\mathrm{A} \beta(1-42)$-induced damage in the CA1 region of the rat hippocampus and promotes cell proliferation in the hippocampal dentate gyrus of adult mice.

In conclusion, these results represent the first evidence of the role of $1,25(\mathrm{OH})_{2} \mathrm{D}_{3}$ and its structural analogue ZK191784 in counteracting the $A \beta(1-42)$ peptide-induced toxicity through the modulation of S1P/S1P1/p38MAPK/ATF4 pathway in differentiated SH-SY5Y cells. 


\section{INTRODUCTION}

The amyloid- $\beta$ peptide $(A \beta)$ is the main constituent of amyloid plaques, and it is believed to play a causative role in the neurodegenerative process occurring in Alzheimer's disease (AD). The molecular mechanism underlying $\mathrm{A} \beta$ toxicity remains largely undefined although accumulating evidence indicates that the binding of hydrophobic $A \beta$ assemblies to cellular membranes triggers multiple effects affecting diverse pathways (Selkoe and Hardy, 2016). A $\beta$ toxicity has been shown to be linked with sphingolipid (SL) metabolism in both cell culture models and animal models (Haughey et al., 2010; Grimm et al., 2013). SLs constitute a biologically active lipid class that is significantly important from both structural and regulatory aspects (Ghasemi et al., 2016; Pyne et al., 2016; Gomez-Muñoz et al., 2016). Indeed, they regulate fundamental cellular processes that are important in determining cellular fate, such as proliferation, apoptosis, cell cycle arrest, senescence, and inflammation (Airola and Hannun, 2013; Maceyka and Spiegel, 2014). Cells maintain a dynamic balance of distinct SL metabolites, with ceramide (Cer) and sphingoid bases serving as activators of cell death pathways, whereas sphingosine-1phosphate (S1P) primarily exerts mitogenic effects acting as intracellular mediator or as ligand of specific S1P receptors (S1PR) (Strub et al., 2010). Of note, it has been proposed that cell fate is regulated by the ratio between $\mathrm{S} 1 \mathrm{P}$ and $\mathrm{Cer} / \mathrm{sphingosine}(\mathrm{Sph})$, with a high ratio promoting cell survival or proliferation, and a low ratio inducing growth arrest or cell death (Cuvillier et al., 1996). Both S1P synthesis and S1PR expression are required for embryonic neurogenesis (Mizugishi et al., 2005), whereas in the adult nervous system, S1P/S1PR axis regulates neurotransmission, promotes survival and affects differentiation (Milstien et al., 2007).

Sphingomyelins (SM) decrease and Cers increase in AD (reviewed in Haughey et al., 2010; Walter and van Echten-Deckert, 2013) with prominent changes in the very long-chain C24:0 and C24:1 species. He et al. (2010) have also demonstrated an increase in Sph level and a decrease of S1P in AD brains compared with age-matched neurologically normal control subjects. More recently, it has been demonstrated that early in $\mathrm{AD}$ pathogenesis and prior to $\mathrm{AD}$ diagnosis, the activity of sphingosine kinase (SphK) activity, the enzyme responsible of S1P synthesis is reduced, while the activity of the enzyme 
responsible for S1P degradation, S1P lyase, is increased (Ceccom et al., 2014; Couttas et al., 2014). Moreover, silencing SphK1 in an animal model of AD accelerates $\mathrm{A} \beta$ deposition and aggravates the memory deficit (Zhang et al.,2013). Changes in SL metabolites have been reported either in experiments in which $A \beta$ has been applied exogenously or when $A \beta$ was produced endogenously. In particular, SHSY5Y neuroblastoma cells incubated with A $\beta$ display a marked down-regulation of SphK1 activity coupled with an increase in the ceramide/S1P ratio followed by cell death (Gomez-Brouchet et al., 2007). Besides its classical function of bone metabolism regulation, $1,25(\mathrm{OH})_{2} \mathrm{D}_{3}$ acts on a variety of tissues including nervous system, where it has neuroprotective, antiproliferating and differentiating effects (Berridge, 2015; DeLuca et al., 2013). Since these processes are also regulated by SLs, these bioactive lipids could be mediators of $1,25(\mathrm{OH})_{2} \mathrm{D}_{3}$ action in neural cells. On this line, we have recently demonstrated that ceramide kinase (CerK), the enzyme involved in Cer phosphorylation, plays a crucial role in the antiproliferative effects of $1,25(\mathrm{OH})_{2} \mathrm{D}_{3}$ in human neuroblastoma cells (Bini et al., 2012). Deficit of $1,25(\mathrm{OH})_{2} \mathrm{D}_{3}$ and several polymorphisms of $1,25(\mathrm{OH})_{2} \mathrm{D}_{3}$ receptor (VDR) have been associated with AD risk (Łaczmański et al., 2015; Annweiler et al., 2015). Moreover, basic research and epidemiological studies have reported that $1,25(\mathrm{OH})_{2} \mathrm{D}_{3}$ plays a protective role against impaired biological processes associated with $\mathrm{AD}$ and reduced cognition, such as those promoted by the toxic peptide.

In this paper, we aimed to investigate the potential involvement of SLs in the neuroprotective action of $1,25(\mathrm{OH})_{2} \mathrm{D}_{3}$ against $\mathrm{A} \beta(1-42)$ toxicity in differentiated SH-SY5Y cells as well as in animal models. SH-SY5Y cells, induced to differentiate by incubation with retinoic acid and BDNF, were used to dissect the potential crosstalk between SLs and $1,25(\mathrm{OH})_{2} \mathrm{D}_{3}$ in preventing the neurotoxicity induced by $A \beta(1-42)$. To evaluate the in vivo neuroprotective effects, we used intracerebral administration of $\mathrm{A} \beta(1-42)$. Specifically, we examined the impact of systemic administration of $1,25(\mathrm{OH})_{2} \mathrm{D}_{3}$ on hippocampal subgranular zone of the dentate gyrus (SGZ) and subventricular zone (SVZ) neurogenesis. Since previous studies have clearly shown that $A \beta$ delivery to the rat hippocampus induces neuronal loss (Stepanichev et al., 2003; Xuan et al., 2012), in the CA1 pyramidal cell layer the $1,25(\mathrm{OH})_{2} \mathrm{D}_{3}$-mediated neuroprotection against $A \beta(1-42)$ was also evaluated. Interestingly, we found that $1,25(\mathrm{OH})_{2} \mathrm{D}_{3}$ 
counteracts $A \beta(1-42)$ toxicity through the axis S1P/S1P1 receptor / p38MAPK/ATF4 in SH-SY5Y cells; on the other hand, $A \beta(1-42)$ injection prevented neurogenesis induced by the hormone in SGZ area. 


\section{Materials and Methods}

\subsection{Materials}

Biochemicals, cell culture reagents, Dulbecco's Modified Eagle's Medium (DMEM), fetal calf serum (FCS), penicillin/streptomycin, protease inhibitor cocktail, and bovine serum albumin, were purchased from Sigma (St. Louis, MO, USA) except phenol red-free Ham's F-12 medium that was from BioSource (Camarillo, CA, USA); SH-SY5Y cells were obtained from American Type Culture Collection (ATCC, Manassa, VA, USA); Lyophilized $\mathrm{A} \beta_{1-42}$ was purchased from Sigma (Milan, Italy) ; D-erythroSphingosine 1-phosphate was from Calbiochem (San Diego, CA,USA); 1,25(OH) $)_{2} \mathrm{D}_{3}$ was from Sigma, Syber Green reagent was from Life Technologies, Thermo Fisher Scientific, Waltham, MA, USA) Chemioluminiscence kit was from GE Healthcare (Chalfont St. Giles, UK); CellTiter 96 Aqueous One Solution Cell Proliferation Assay kit was from Promega (Madison, WI, USA); anti-phospho-p38 and total p38 antibodies from Cell Signalling (Danvers, MA, USA); anti-BAX, anti-ATF4, anti- $\beta$-actin antibodies and secondary antibodies conjugated to horse radish peroxidase were from Santa Cruz Biotechnology (Santa Cruz, CA, USA); anti-S1P1 was from Sigma (Milan, Italy); anti guinea-pig IgG antibody conjugated with Alexa488 (Jackson ImmunoResearch Laboratories, Suffolk, UK). Guinea pig polyclonal antibody anti-NeuN were from (Millipore, Vimodrone, Italy). BrdU (rat IgG monoclonal, Bio-Rad Laboratories, Biotinylated antibodies were from Vector Labs, Burlingame, CA, USA); O.C.T. was from Tissue-Tek (Sakura Finetek USA, Inc. Torrance, CA USA); avidin-biotin-peroxidase kit was from Vector Labs (Vector Laboratories LTD, Peterborough, UK); $\left[{ }^{3} \mathrm{H}\right]$ serine, $\left[{ }^{3} \mathrm{H}\right]$ Sphingosine and $\left[{ }^{32} \mathrm{P}\right] \mathrm{ATP}$ (6000Ci/mmol) were from Perkin Elmer (Monza, Italy). W146 was from Tocris Bioscience (Bristol, UK). ZK191784, and ZK159222 were kindly provided by Bayer Shering Pharma AG (Berlin, Germany); Yoyo-1, was from Life Technologies; ketamine was from Ketavet (Gellini, Aprilia, Italy) and xylazine (Rompun; Bayer, Germany) Sintex (Nuova Chimica, Cinisello Balsamo, Italy).

\subsubsection{Animals}


Fully adult Long-Evans hooded rats (350 g) and adult (3 months-old) CD1 male mice bred in animal facilities at CNR (Pisa, Italy) and Neuroscience Institute Cavalieri Ottolenghi (Turin, Italy) were used in this study. Animals were housed in a $12 \mathrm{~h} \mathrm{light/dark} \mathrm{cycle} \mathrm{with} \mathrm{food} \mathrm{and} \mathrm{water} \mathrm{available} \mathrm{ad} \mathrm{libitum.} \mathrm{All}$ experimental procedures were in conformity to the European Communities Council Directive 86/609/EEC and were approved by the Italian Ministry of Health.

\subsubsection{SH-SY5Y cell culture and treatments}

SH-SY5Y cells were grown in DMEM/HAM's F12 supplemented with 10\% heat-inactivated fetal bovine serum and $100 \mathrm{U} / \mathrm{mL}$ penicillin/streptomycin (Bini et al., 2012). The cells were maintained at $37^{\circ} \mathrm{C}$ in a humidified incubator with $5 \% \mathrm{CO}_{2}$ and $95 \%$ air. Medium was changed every other day and the cells were split $(0.25 \%$ trypsin, $0.53 \mathrm{mM}$ EDTA solution) when they reached approximately $80 \%$ confluence. All treatments were performed for $24 \mathrm{~h}$ using cells at approximately $60-70 \%$ confluence. Differentiation was induced with $10 \mu \mathrm{M}$ retinoic acid (RA) for 5 days. Cells were then treated with $100 \mathrm{nM} 1,25(\mathrm{OH})_{2} \mathrm{D}_{3}, 250$ nM ZK159222 (the inactive analogue), or $250 \mathrm{nM}$ ZK191784 for $24 \mathrm{~h}$ and then in the presence or absence of $1 \mu \mathrm{M} A \beta(1-42)$ peptide for $6 \mathrm{~h}$. To obtain $A \beta(1-42)$ oligomeric aggregates, the peptide solution was prepared as in (Dahlgren et al., 2002), whereas for unaggregated conditions, the $A \beta(1-42)$ was prepared as above and diluted immediately without incubation into cell culture media.

\subsection{Cell proliferation and neurite length}

Cell proliferation was determined by cell counting using Burker camera and cytometer (Frati et al., 2015). Specifically, cells were plated at a density of $5 \times 10^{4}$ cells/well in a 6-well plate in growth medium, synchronized and treated for $24 \mathrm{~h}$ as reported above. Cytometric analysis was performed using The Tali $^{\circledR}$ Image-Based Cytometer (Thermo Fisher Scientific), a 3-channel benchtop assay platform that captures up to 20 images (fields of view) per sample, automatically analyses the images with sophisticated digital image-based cell counting and fluorescence detection algorithms (Remple and Stone, 2011). The Tali ${ }^{\circledR}$ Cell Cycle Kit was used to count living and dead cells and the percentage of cells in each phase of 
the cell cycle. Aliquot of cells $\left(0.5-1 \times 10^{6}\right)$ from each sample was processed according to the manufacturer's instructions. Neurite length was determined after cell differentiation treatment. Images recorded with a Leica inverted light microscope $(\times 20$ objective lens $)$ equipped with a Nikon camera were saved in .TIFF format. Neurite length was determined manually by ImageJ software using the segmented line tool. Five-seven neurites were counted per field and four-five fields per well.

\subsection{Cell viability assay}

Cell viability was assessed by 3-(4,5-dimethylthiazol-2-yl)-5-(3-carboxymethoxyphenyl)-2- (4sulfophenyl)-2H-tetrazolium (MTS) assay (Sassoli et al., 2011). Briefly, SH-SY5Y cells in 96-well plates were plated at $50 \%$ confluence and synchronized in serum-free medium for $24 \mathrm{~h}$. Then, cells were incubated in medium containing $10 \%$ fetal calf serum, and pre-treated with specific inhibitors for $30 \mathrm{~min}$ before the addition of $1,25(\mathrm{OH})_{2} \mathrm{D}_{3}$ and its analogues for further $24 \mathrm{~h}$. A CellTiter 96 Aqueous One Solution Cell Proliferation Assay kit was utilized to measure a formazan product, which is directly proportional to the cell viability. Optical density at $490 \mathrm{~nm}$ was determined using an ELISA microplate reader (Bio-Rad, Hercules, CA, USA).

\subsection{Western blotting analysis}

Immunoblotting was performed using enhanced chemiluminescence as previously reported (Meacci et al., 2010, Squecco et al., 2006). SH-SY5Y cells were lysed for $30 \mathrm{~min}$ at $4{ }^{\circ} \mathrm{C}$ in a buffer containing $50 \mathrm{mM}$ Tris-HCl, pH 7.5, $120 \mathrm{mM} \mathrm{NaCl}, 1 \mathrm{mM}$ EDTA, 6 mM EGTA, $15 \mathrm{mM} \mathrm{Na}_{4} \mathrm{P}_{2} \mathrm{O}_{7}, 20 \mathrm{mM} \mathrm{NaF}, 1 \%$ Nonidet and protease inhibitor cocktail (1.04 mM AEBSF, $0.08 \mathrm{mM}$ aprotinin, $0.02 \mathrm{mM}$ leupeptin, $0.04 \mathrm{mM}$ bestatin, $15 \mu \mathrm{M}$ pepstatin A, $14 \mu \mathrm{M}$ E-64). To prepare total cell lysates, cell extracts were centrifuged for 5 $\min$ at $5,000 \mathrm{xg}$ at $4{ }^{\circ} \mathrm{C}$. Proteins $(10-25 \mu \mathrm{g})$ from lysates were resuspended in Laemmli's sodium dodecylsulfate (SDS) sample buffer. Samples were subjected to SDS-polyacrylamide gel electrophoresis (SDSPAGE) and Western analysis as previously described (Squecco et al., 2006). The blots were first blocked in 5\% milk in Tris-buffered saline with $0.1 \%$ Tween 20 (T-TBS) at room temperature for $1 \mathrm{~h}$, and then incubated in the same blocking solution containing primary antibodies overnight at $4^{\circ} \mathrm{C}$. After 
sufficient washes with T-TBS, blots were incubated with appropriate horseradish peroxidase-conjugated secondary antibodies for $1 \mathrm{~h}$. Blots were again washed in T-TBS and, thereafter, signals were detected by using ECL reagent. Finally, blots were exposed to high-performance chemiluminescence film. Densitometric analysis of the bands was performed using NIH IMAGE (ImageJ software, Bethesda, MD, USA) and Quantity-One (Imaging and Analysis Software by Bio-Rad Laboratories, Hercules, CA) and band intensity was reported as relative percentage (means \pm SEM), obtained by calculating the ratio of specific protein on $\beta$-actin intensity and normalizing to control, set as 100 .

\subsection{In vivo determination of the effect of $1,25(\mathrm{OH})_{2} \mathrm{D}_{3}$ on neuroprotection}

\subsubsection{Intrahippocampal injection of $A \beta(1-42)$ in rats}

The main aim of the experiment was to test the neuroprotective effects of $1,25(\mathrm{OH})_{2} \mathrm{D}_{3}$ after intrahippocampal injection of aggregated $A \beta(1-42)$. For these studies, we used rats since there is more literature available (as compared to mice) on $\mathrm{A} \beta(1-42)$-induced hippocampal toxicity (e.g. Amtul et al., 2014; Villette et al., 2012). All experimental animals $(n=10)$ received an injection of aggregated $A \beta(1-42)$ into the hippocampus to trigger neuronal degeneration. They were treated with intraperitoneal injections of either v e h i c 1 e ( saline, $\mathrm{n}=4)$ or $1,25(\mathrm{OH})_{2} \mathrm{D}_{3}(1 \mu \mathrm{g} / \mathrm{day} / \mathrm{kg} ; \mathrm{n}=6)$ for 6 consecutive days before the hippocampal delivery of aggregated $\mathrm{A} \beta(1-42) .1,25(\mathrm{OH})_{2} \mathrm{D}_{3} /$ saline treatment was continued at days 8-1113-15-18 after $\mathrm{A} \beta(1-42)$. The dosing regime of $1,25(\mathrm{OH})_{2} \mathrm{D}_{3}$ was determined based on previous rat studies (e.g. Vieth et al., 1990). To obtain Aß(1-42) oligomeric aggregates, the peptide solution was prepared as in (Dahlgren et al., 2002). Briefly, the lyophilised $A \beta(1-42)$ peptide was dissolved in hexafluoro-2isopropanol to $1.0 \mathrm{mM}$ and then the solvent was evaporated. $\mathrm{A} \beta(1-42)$ oligomers were prepared by suspending the peptide in dimethyl sulfoxide to a concentration of $5 \mathrm{mM}$. For oligomeric conditions, Ham's F-12 was added to bring the peptide to a final concentration of $100 \mu \mathrm{M}$. Then, the sample was centrifuged at $16,000 \mathrm{rpm}$ for $20 \mathrm{~min}$, the pellet discarded and the supernatant incubated at $4{ }^{\circ} \mathrm{C}$ for $24 \mathrm{~h}$ without agitation. No significant destabilisation of the oligomers or change in their structures or morphologies could 
be detected after this procedure, as previously reported (Campioni et al., 2010).

For the intrahippocampal injections, rats were anesthetized with avertin and placed in a stereotaxic frame. Injections of $1 \mu \mathrm{L}$ of a $1 \mathrm{mg} / \mathrm{mL}$ solution of aggregated $\mathrm{A} \beta(1-42)$ were made at the following coordinates (in mm with respect to bregma): A-P-3.8; M-L 2.5; H 2.6 below dura (Costantin et al., 2005; Antonucci et al., 2010; Caleo et al., 2012, 2013).

\subsubsection{Immunohistochemistry and stereological analysis of lesion size in rat CA1}

Selected coronal sections were also stained for the neuronal marker NeuN using a guinea pig polyclonal antibody $(1: 1,000)$. Sections were blocked with $10 \%$ normal donkey serum in PBS containing $0.5 \%$ Triton $\mathrm{X}-100$ and then incubated overnight at $4{ }^{\circ} \mathrm{C}$ with the primary antibody. On the following day, sections were rinsed and incubated for $2 \mathrm{~h}$ at room temperature in a solution containing the secondary antibody conjugated with Alexa488 (-1:500). Sections were washed in PBS and mounted using an anti-fading agent (Vectashield).

\subsection{In vivo determination of the effect of $1,25(\mathrm{OH})_{2} \mathrm{D}_{3}$ on neurogenesis}

\subsubsection{Animals and Experimental procedures}

We decided to employ mice for these experiments, as our groups have obtained previous data of hippocampal and SVZ proliferation in this species (Rossi et al., 2006, Oboti et el., 2009). Four groups (groups 1-4; $\mathrm{n}=5$ animals/group) of male mice ( 3 months old) were used for this experiment. Groups 1 and 2 were intraperitoneally (ip) injected with $1,25(\mathrm{OH})_{2} \mathrm{D}_{3}(1.0 \mu \mathrm{g} / \mathrm{kg} /$ day $)$ for five consecutive days. The following day (day sixth) Group 1 was injected with aggregated $\mathrm{A} \beta(1-42)(5 \mu \mathrm{g}$ diluted in $2 \mu \mathrm{L}$ of saline solution) into the left lateral ventricle. Group 2 was equally treated, but injected with unaggregated $A \beta(1-42)$ (vehicle). Additional $1,25(\mathrm{OH})_{2} \mathrm{D}_{3}$ ip injections $(1.0 \mu \mathrm{g} / \mathrm{kg} /$ day $)$ were performed in Groups 1 and 2 at days 8 and 11 . The dose of $1,25(\mathrm{OH})_{2} \mathrm{D}_{3}$ was determined on the basis of previous studies in mice (Chow et al., 2011; Zhu et al., 2012). Groups 3 and 4 served as $1,25(\mathrm{OH})_{2} \mathrm{D}_{3}$ controls. Both were treated for five days with ip injections of saline solution $(0.9 \% \mathrm{NaCl})$. At day sixth groups 3 and 4 were stereotaxically injected into the left 
lateral ventricle with aggregated $A \beta(1-42)$ or unaggregated $A \beta(1-42)$. At days 8 and 11 were performed two additional ip injections of saline solution in bothgroups.

\subsubsection{Tissue preparation}

Animals were deeply anesthetized with an intraperitoneal injection of ketamine and xylazine 3:1 solution and transcardially perfused with $0.9 \%$ saline solution followed by cold $4 \%$ paraformaldehyde (PFA) in 0.1M phosphate buffer (PBS), pH 7.4. Brains were removed from skull and post-fixed for 4-6 hours in 4\% PFA at $4^{\circ} \mathrm{C}$, followed by a cryopreservation step using a $30 \%$ sucrose solution in $0.1 \mathrm{M} \mathrm{PB} \mathrm{pH} 7.4$ at $4{ }^{\circ} \mathrm{C}$. Brains were included in OCT then frozen and cryostat-sectioned. Free floating coronal sections $(25 \mu \mathrm{m})$ were collected in multi-well dishes in representative series. Sections were stored at $-20^{\circ} \mathrm{C}$ in antifreeze solution (30\% ethylene glycol, 30\% glycerol, 10\% PBS pH 7.4) until use.

\subsubsection{Quantification of hippocampal and SVZ neurogenesis}

BrdU immunohistochemistry. After rinsing in PBS to remove the antifreeze solution, sections were pretreated with $2 \mathrm{~N} \mathrm{HCl}$ for 30 minutes at $37^{\circ} \mathrm{C}$, for antigene retrieval, and neutralized with borate buffer, $\mathrm{pH}$ 8.5, for 10 minutes. Next, sections were incubated for $24 \mathrm{~h}$ at $4^{\circ} \mathrm{C}$ in anti-BrdU (1:5000) diluted in $0.01 \mathrm{M}$ PBS, $\mathrm{pH} 7.4,0.5 \%$ TritonX-100, and $1 \%$ normal serum, made in the same host species of the secondary antibody. Then, sections were incubated for $1 \mathrm{~h}$ at room temperature in secondary biotinylated antibody followed by the avidin-biotin-peroxidase complex. To reveal immunoreactivity, we used $0.015 \% 3,3$ 'diaminobenzidine and $0.0024 \% \mathrm{H}_{2} \mathrm{O}_{2}$ in $0.05 \mathrm{M}$ Tris- $\mathrm{HCl}$, $\mathrm{pH}$ 7.6. After adhesion on gelatin coated glass slides, sections were dehydrated and mounted in Sintex. The number of BrdU-immunoreactive cells in the dentate gyrus was estimated by using Stereo Investigator software (MicroBrightField, Colchester, VT, USA). All BrdU-positive cells in the granule cell layer and subgranular zone of every sixth section throughout the entire rostro-caudal extent of the hippocampus were counted, and the resulting number of cells was multiplied by six to give an estimate of the total number of BrdU-labelled cells in each individual animal (Rossi et al., 2006). All counts were performed blind to experimental treatment.

Quantification of SVZ neurogenesis. Cell counts and image analyses were performed on a Nikon microscope equipped with a computer-assisted image analysis system (Neurolucida software; Micro- 
BrightField). Brightness, color, and contrast were balanced and assembled into panels with Inkscape (Free vector graphics editors). All cell counts were performed blind to the genotype and/or the treatment. Cells were counted through the $25 \mu \mathrm{m}$ thickness of the slice in one square of the grid (one of every two) by sequential translation of the counting frame until the area of interest was entirely covered (40x objective). This procedure allowed us to analyze about one-fourth of the area of interest. The number and position of each cell in the counted area were marked by the software. Cells contacting a line on the upper or left edge of the counting square were excluded from the counts, whereas those contacting the lower or right edge of the square were considered in the counts. Cell density (number of labeled profiles $/ \mathrm{mm}^{3}$ ) was calculated by multiplying the area measurements for the mean section thickness $(25 \mu \mathrm{m})\left[\Sigma\right.$ of sampled areas $\mu \mathrm{m}^{2}$ $\times 25 \mu \mathrm{m}]$.

\subsection{Sphingolipid determination}

Cer and S1P measurement was achieved as described in Frati et al. (2015) and Pierucci et al. (2016). Briefly, SH-SY5Y cells were labeled with $40 \mu \mathrm{Ci} / \mathrm{ml}$ of $\left[{ }^{3} \mathrm{H}\right]$ palmitate for $24 \mathrm{~h}$ in serum free-medium in the presence or absence of agonists for Cer quantification. Cells were then washed twice with ice-cold calciumfree phosphate-buffered saline and scraped into $1 \mathrm{~mL}$ of methanol and successively mixed with $0.5 \mathrm{~mL}$ of chloroform. Lipids were extracted by separation of phases with a further $0.5 \mathrm{~mL}$ of chloroform and 0.9 mLof a solution containing $2 \mathrm{M} \mathrm{KCl}$ and $0.2 \mathrm{M} \mathrm{HCl}$. Chloroform phases were dried down under a stream of nitrogen and lipids were separated by thin-layer chromatography (TLC) using silica gel 60coated glass plates. The plates were developed for $50 \%$ of their lengths with chloroform/methanol/acetic acid $(9: 1: 1, \mathrm{v} / \mathrm{v} / \mathrm{v})$ and then dried. They were then developed for their full length with petroleum ether/diethylether/acetic acid (60:40:1, v/v/v). Radioactivity of the samples, obtained by scraping the Cer and C1P spots from the plates, was quantified by liquid scintillation counting (Beckman LS1000-counter). S1P was quantified essentially as reported in De Palma et al. (2006) and Pierucci et al. (2016). Differentiated cells were incubated with serum-free medium and $2 \mu \mathrm{Ci}$ of $\left[{ }^{3} \mathrm{H}\right]$ serine for $24 \mathrm{~h}$. Total lipids were extracted by the addition to cells of $\mathrm{CHCl}_{3}: \mathrm{CH}_{3} \mathrm{OH}: \mathrm{HCl}$ (100:200:1, vol:vol:vol). Lower phase was evaporated and lipids separated by TLC on Silica Gel 60 with $\mathrm{CH}_{3}\left(\mathrm{CH}_{2}\right)_{3} \mathrm{OH} / \mathrm{CH}_{3} \mathrm{COOH} / \mathrm{H}_{2} \mathrm{O}(3: 1: 1$, 
vol:vol:vol). The radioactive spots corresponding to S1P were identified and quantified by liquid scintillation counting.

\subsection{Sphingosine kinase activity measurement}

SphK activity was determined essentially as described in (Bini et al., 2012, Frati et al., 2015). Briefly, equal amounts of protein $(60 \mu \mathrm{g})$ from SH-SY5Y cells were incubated in assay buffer in the presence of 20 $\mu \mathrm{mol} / \mathrm{L}$ Sph and $200 \mathrm{mmol} / \mathrm{L}$ ATP $\left(\left[{ }^{32} \mathrm{P}\right] \mathrm{ATP}(3 \mu \mathrm{Ci} /\right.$ assay). SphK activity was measured in a typical buffer solution for detecting mainly SphK1 isoform activity. Reactions were started with the addition of lysate proteins and incubated for $30 \mathrm{~min}$ at $37^{\circ} \mathrm{C}$. The formed $\left.{ }^{[32} \mathrm{P}\right] \mathrm{S} 1 \mathrm{P}$ in the organic phase was separated by thin layer chromatography (TLC) on Silica Gel 60 using $\mathrm{CH}_{3}\left(\mathrm{CH}_{2}\right)_{3} \mathrm{OH} / \mathrm{CH}_{3} \mathrm{COOH} / \mathrm{H}_{2} \mathrm{O}$ (3:1:1, vol:vol:vol) (Frati et al., 2015). The radioactive spots corresponding to authentic S1P was identified and quantified by scraping from the plates and counting theradioactivity

\subsection{Reverse transcription and Real-time PCR}

RNA isolation. Total RNA was isolated by extraction with TRIREAGENT, according with the manufacturer's instructions. Concentration and purity of extracted total RNA were evaluated as described in Pierucci et al. (2016).

Reverse transcription and PCR analysis. One-two $\mu \mathrm{g}$ of total RNA from cells were reverse- transcribed to single stranded cDNA using the commercially available cDNA Synthesis Kit (SuperScript ${ }^{\circledR}$ III cells Direct cDNA Synthesis Kits, according to the manufacturer's instructions. Samples were incubated at $25^{\circ} \mathrm{C}$ for 5 $\min$, at $42^{\circ} \mathrm{C}$ for $50 \mathrm{~min}$ and then at $85^{\circ} \mathrm{C}$ for $5 \mathrm{~min}$ in a thermal cycler (Perkin Elmer).

Real time PCR. Quantitative real-time PCR was carried out using the 7500FAST System (Applied Biosystems, Darmstad, Germany) as previously reported (Frati et al., 2015). A set of primers (200 nM) for ATF4 gene (forward primer: 5'AAACCTCATGGGTTCTCCAG3' and reverse primer:

5'CATCCTCCTTGCTGTTGTTG3') and $\beta$-actin (forward primer:5'GGCACCACCATGTACCC 3' reverse primer: 5'ATGTGGATCAGCAAGCAG3') were used. The expression of ATF4 genes were quantified in comparison with the housekeeping gene $\beta$-actin. PCR amplifications were performed on 
cDNA samples corresponding to a final RNA concentration of $50 \mathrm{ng}$. PCR was performed in a total volume of $25 \mu \mathrm{L}$ containing PCR Master mix and $2 \mu \mathrm{L}$ of cDNA. Reaction conditions were as follows: $95^{\circ} \mathrm{C}$ for 10 min, followed by 40 cycles at $95^{\circ} \mathrm{C}$ for $30 \mathrm{~s}$ alternating with $58^{\circ} \mathrm{C}$ or $55^{\circ} \mathrm{C}$ for $30 \mathrm{~s}$ and $72^{\circ} \mathrm{C}$ for $45 \mathrm{~s}$. PCR amplifications were run in duplicates. Blank controls, consisting in no template (water) or RT negative reactions, were performed in each run. The results of the real-time PCR were presented as Ct values, where Ct was defined as the PCR threshold cycle at which amplified product was first detected. All values were normalized to the $\beta$-actin housekeeping gene expression and $\Delta \mathrm{Ct}$ calculated.

\subsection{Statistical analysis}

Data are presented as mean \pm SEM. The results are compared using Student's $t$-test between two groups, or using ANOVA followed by post hoc test among three groups or more. For the in vivo analysis of neurogenesis, we employed two way ANOVA (two factors: systemic treatment vehicle/1,25(OH $)_{2} \mathrm{D}_{3}$ and intracerebral injection - unaggregated/aggregated $\mathrm{A} \beta(1-42)$, followed by

a post-hoc Multiple Comparison Procedure (Tukey Test). A value of $\mathrm{P}<0.05$ was considered significant. For neurite length determination, mean values were obtained by averaging values from the measurement of approximately 50 neurites per well in two separate wells ( $n=3$ independent experiments) (ttest, two-way ANOVA). 


\section{RESULTS}

\section{1. $1,25(\mathrm{OH})_{2} \mathrm{D}_{3}$ prevents $\mathrm{A} \beta$-induced cytotoxicity in differentiated $\mathrm{SH}-\mathrm{SY} 5 \mathrm{Y}$ cells.}

SH-SY5Y cells have been differentiated by treatment with RA for 5 days and BDNF for 3 days, and treated in the presence or the absence of $100 \mathrm{nM} 1,25(\mathrm{OH}) 2 \mathrm{D} 3$ for $24 \mathrm{~h}$ and in the presence or the absence of 1

$\mu \mathrm{M} A \beta$ for 6 hours, as described in Material and Methods. The incubation in the presence of $\mathrm{A} \beta$ induced morphological changes in differentiated SH-SY5Y neuroblastoma cells. Fig. 1A-B show that this treatment led to the reduction of neurite length.

The treatment with $A \beta$ reduced cell number (Fig. 1C) and decreased mitochondrial function, measured as capability of MTS reduction (Fig 1D) and BAX mitochondrial localization (Fig 1E). These effects were prevented by $1,25(\mathrm{OH}) 2 \mathrm{D} 3$ treatment for $24 \mathrm{~h}$ prior $\mathrm{A} \beta(1-42)$ administration. Similarly, the structural analogue of $1,25(\mathrm{OH}) 2 \mathrm{D} 3, \mathrm{ZK}$ 191784, prevented the toxic effect of on cell cycle, whereas the inactive analogue, ZK156722 was ineffective. In fact, as shown in Fig.1F the percentage cells in G0/G1 significantly increased in the presence of $A \beta(1-42)$. Notably, the treatment with 1,25(OH)2D3 or ZK191784 prior of $\mathrm{A} \beta(1-42)$, induced a reduction of the percentage of cells in this phase, whereas the cells in S and G2 phase were significantly increased respect to A $\beta$ alone, and ZK159222 was ineffective. All these results suggest a protective effect of $1,25(\mathrm{OH}) 2 \mathrm{D} 3$ and its analogue respect to the cytostatic/toxic effect of $\mathrm{A} \beta(1-42)$.

\subsection{Chronic $1,25(\mathrm{OH})_{2} \mathrm{D}_{3}$ treatment reduces $A \beta(1-42)$-induced neuronal damage in $\mathrm{CA} 1$ subfield of rat hippocampus}

To confirm the neuroprotection elicited by $1,25(\mathrm{OH})_{2} \mathrm{D}_{3}$ treatment in vivo, adult rats were pre-treated with either $1 \mu \mathrm{g} / \mathrm{day} / \mathrm{kg} 1,25(\mathrm{OH})_{2} \mathrm{D}_{3}$ or saline for 6 days and then challenged with an intrahippocampal injection of aggregated $\mathrm{A} \beta(1-42)(1 \mu \mathrm{L}$ of a $1 \mathrm{mg} / \mathrm{mL}$ solution) as described in Materials and Methods. 
Lesion size was determined by stereology at day 21 . In all animals, the site of neuronal loss was localized in the CA1 subfield of the hippocampus (Fig. 2), and there was no evidence of neuronal loss in the contralateral side. The percentage of neuronal loss in animal treated with $1,25(\mathrm{OH})_{2} \mathrm{D}_{3}$ was significantly reduced compared with the control group suggesting that rats chronically-treated with the hormone exhibit protection against $A \beta(1-42)$-induced toxicity.

\subsection{Impact of $1,25(\mathrm{OH})_{2} \mathrm{D}_{3}$ on neurogenesi}

We quantified cell proliferation in both the SVZ and SGZ of the dentate gyrus of mice treated with aggregated/unaggregated $A \beta(1-42)$ and 1,25(OH)2D3. To label dividing cells we administered systemically the thymidine analogue BrdU. We found that the treatment with $1,25(\mathrm{OH}) 2 \mathrm{D} 3$ or $\mathrm{A} \beta(1-42)$ (alone and in combination) did not affect cell proliferation in SVZ (Fig 3A). Surprisingly in the dentate gyrus (DG), the hormone significantly enhanced the number of BrdU-positive cells with respect to controls (Fig. 3B), suggesting a different responsiveness to $1,25(\mathrm{OH}) 2 \mathrm{D} 3$ of the two neurogenic zones. When $1,25(\mathrm{OH}) 2 \mathrm{D} 3$ and aggregated $\mathrm{A} \beta(1-42)$ were used in combination, the toxic peptide abrogated the proliferative effect of $1,25(\mathrm{OH}) 2 \mathrm{D} 3$. These findings suggest a distinctive susceptibility to the effect of $1,25(\mathrm{OH}) 2 \mathrm{D} 3$ of neural cell precursors from different niches and the ability of aggregated $\mathrm{A} \beta(1-42)$ to counteract the proliferative effect of the hormone.

\section{4. $1,25(\mathrm{OH})_{2} \mathrm{D}_{3}$ prevented $\mathrm{A} \beta(1-42)$-induced cytotoxicity affecting sphingolipid content and sphingosine kinase activity in differentiated SH-SY5Y neuroblastoma cells}

The molecular mechanisms involved in $1,25(\mathrm{OH})_{2} \mathrm{D}_{3}$ action are not fully investigated. Recently, we demonstrated that Cer/CerK play a role in the antiproliferative effect of $1,25(\mathrm{OH})_{2} \mathrm{D}_{3}$ in neuroblastoma cells (Bini et al., 2012). Therefore, in order to establish the involvement of SLs in the neuroprotective action of the hormone, we measured the activity of the SphK, the enzyme that catalizes the 
phosphorylation of sphingosine leading to S1P formation (Fig. 4A) aggregated oligomers $\mathrm{A} \beta(1-42)$ induced a strong reduction of SphK activity (up to $70 \%$ of the control) and in the presence of $1,25(\mathrm{OH})_{2} \mathrm{D}_{3}$ the reduction of enzyme activity is significantly less pronounced.

In addition, differentiated SH-SY5Y cells were labeled for $24 \mathrm{~h}$ with ${ }^{3} \mathrm{H}$-serine before treatment with

$1,25(\mathrm{OH})_{2} \mathrm{D}_{3}$ and the toxic peptide as described in Material and Methods. The radioactivity associated with Cer and S1P were measured. As shown in Fig. $4 \mathrm{BC}$, either $1,25(\mathrm{OH})_{2} \mathrm{D}_{3}$ or $\mathrm{A} \beta(1-42)$ induced a significant decrease of $\left[{ }^{3} \mathrm{H}\right]$ - labeled S1P, whereas it determined an increase of $\left[{ }^{3} \mathrm{H}\right]$-labeled Cer. The incubation in the presence of both $1,25(\mathrm{OH})_{2} \mathrm{D}_{3}$ and $\mathrm{A} \beta(1-42)$ restored the basal levels of either S1P and Cer. On the other hand, no significant difference was observed for SM and sphingosine content (data not shown).

The control of cell fate depends on S1P/Cer rheostat, therefore, when we calculated this ratio, we found that the treatment with $\mathrm{A} \beta$ elicited a strong reduction that was partially reverted by $1,25(\mathrm{OH})_{2} \mathrm{D}_{3}$ (Table 1 ), suggesting that the hormone is able to control the balance between the prosurvival factor, S1P, and the proapoptotic factor, ceramide.

\subsection{1,25( $(\mathrm{OH})_{2} \mathrm{D}_{3}$ exerts its neuroprotective action through $\mathrm{S} 1 \mathrm{P} / \mathrm{S} 1 \mathrm{P} 1$ axis}

Since S1P1 expression is altered in AD (Ceccom et al., 2014), we have also investigated whether incubation with $1,25(\mathrm{OH})_{2} \mathrm{D}_{3}$ or/and the toxic peptide modulated S1P1 expression in differentiated SHSY5Y cells. As reported in Fig $5 \mathrm{AB}, 1,25(\mathrm{OH})_{2} \mathrm{D}_{3}$ slightly increased $\mathrm{S} 1 \mathrm{P} 1$ expression, whereas $A \beta(1-42)$ led to a decrease in receptor expression. Notably, the reduced expression of this receptor subtype elicited by $\mathrm{A} \beta(1-42)$ was prevented by $1,25(\mathrm{OH})_{2} \mathrm{D}_{3}$ treatment, suggesting that the hormone can interfere with the signaling downstream to S1P receptor.

Conversely, the quantification of S1P1 mRNA expression by real time PCR did not show any significant difference either in the presence of $1,25(\mathrm{OH})_{2} \mathrm{D}_{3}$ or the combination of $1,25(\mathrm{OH})_{2} \mathrm{D}_{3}$ and $\mathrm{A} \beta(1-42)$ (Fig. 5C), suggesting that the S1P1 expression reduction might be due to protein degradation rather than to 
gene transcription.

\section{6. $\mathrm{S} 1 \mathrm{P} / \mathrm{S} 1 \mathrm{P} 1$ axis regulates $\mathrm{p38}$ MAPK/ATF4 system}

It is known that increased p38 MAPK activity are associated with the neuropathology of AD patients (Sun et al., 2003) and ER stress, we finally investigated whether p38 MAPK was downstream to S1P1 in differentiated SH-SY5Y cells. When SH-SY5Y cells were incubated in the presence of the S1P1 antagonist W146, the expression of the active phosphorylated form of p38 MAPK was significantly decreased, suggesting that p38 MAPK is downstream to $\mathrm{S} 1 \mathrm{P} 1$ receptor (Fig.6AB). Notably, $1,25(\mathrm{OH})_{2} \mathrm{D}_{3}$ as well as ZK191784 treatment prior the toxic peptide $A \beta(1-42)$ could also prevent the increase of active p38 MAPK elicited by the peptide as well as tunicamycin, a commonly used ER stress inducer (Fig. 6CD). Finally, we examined whether $1,25(\mathrm{OH})_{2} \mathrm{D}_{3}$ and its analogue could exert its neuroprotective action by regulating the expression of ER stress-induced transcription factor activating-transcription-factor-4 (ATF4) (Wei et al., 2015), implicated in the regulation of synaptic plasticity and memory (Pasini et al., 2015). The changes in the expression levels of ATF-4 were investigated by real time PCR (data not shown) as well as Western Blotting in SH- SY5Y cells treated with $1,25(\mathrm{OH})_{2} \mathrm{D}_{3}$ or its analogue prior $\mathrm{A} \beta(1-42)$ or tunicamycin. As shown in Fig.7AB, treatment with aggregated $A \beta(1-42)$ oligomers induced the upregulation of ATF4 protein expression that was reduced in the presence of $1,25(\mathrm{OH})_{2} \mathrm{D}_{3}$ or ZK191784. 


\section{DISCUSSION}

Increasing evidence indicates that $1,25(\mathrm{OH}) 2 \mathrm{D} 3$ has a neuroprotective role in the nervous system, including AD neurodegeneration (Eyles et al., 2013; DeLuca et al., 2013; Grimm et al., 2014). The mechanism of neuroprotection against $\mathrm{A} \beta(1-42)-$ induced toxicity might include anti-inflammatory actions, antioxidant effects, control of calcium homeostasis, anti-atrophic effects through the increased expression of neurotrophins and attenuation of $A ß$ peptide accumulation (Annweiler et al., 2014, Landel et al., 2016). Most of these processes are also regulated by bioactive SLs (Ghasemi et al., 2016; Pyne et al., 2016; GomezMuñoz et al., 2016). The aim of the present study was to investigate whether 1,25(OH)2D3 and SLs, in particular the pro-survival factor S1P, could act synergistically on neurogenesis and on neuroprotection against $A \beta(1-42)-$ induced toxicity.

We provide the first demonstration that $1,25(\mathrm{OH}) 2 \mathrm{D} 3$ and its structural analogue ZK191784 counteract the $\mathrm{A} \beta(1-42)$ peptide-induced toxicity through the modulation of S1P/S1P1/p38MAPK/ATF4 pathways in differentiated SH-SY5Y cells. The dose of A $(1-42)$ used in the in vitro experiments was able to induce cell cycle arrest, and it had only a minor effect on cell death. Therefore, this approach allows to better assess the combined effects of different cell signaling pathways. We also present preliminary in vivo evidence on the potential role of $1,25(\mathrm{OH}) 2 \mathrm{D} 3$ as a neuroprotective factor. The experimental conditions used in vivo mimic an acute increase of $A \beta(1-42)$ levels in the brain parenchyma thus allowing the development of Alzheimer-like neurotoxicity.

An early event in $\mathrm{AD}$ pathogenesis is the drastic reduction of S1P content due to the changes in the activity of the enzymes responsible for its synthesis and degradation, SphK and S1P lyase (Takasugi et al., 2011; Ceccom et al., 2014; Couttas et al., 2014). In agreement with these findings, we show reduced SphK activity and enzyme phosphorylation in SH-SY5Y cells treated with A $\beta$, and, interestingly, $1,25(\mathrm{OH}) 2 \mathrm{D} 3$ treatment leads to recovery of the basal level of S1P. These results extend those obtained by Ceccom et al., (2014) and Gomez-Brouchet et al. (2007) that reported a reduction of S1P content and protein SphK1 expression by $\mathrm{A} \beta$ in cell culture studies as well as in $\mathrm{AD}$ patients.

Very recently, AlzPathway, a comprehensive knowledge repository of protein-protein and gene 
regulatory networks in $\mathrm{AD}$, has been updated and Cer has been highlighted as one of the main players in the pathogenesis of $\mathrm{AD}$ (Mizuno et al., 2016). In fact, increasing levels of Cer have also been found in cell and animal models of $\mathrm{AD}$ and in AD patients; Cer has been also shown to stabilize APP cleaving via $\beta$ secretase (Puglielli et al., 2003). Notably, in our experiments,

$1,25(\mathrm{OH}) 2 \mathrm{D} 3$ is able to re-set the ratio $\mathrm{S} 1 \mathrm{P} / \mathrm{Cer}$ in favour of the pro-survival effect by reducing the increase of Cer elicited by $\mathrm{A} \beta$.

The bioactive lipid S1P is released by many cell types, including neurons and, by acting as a ligand, it triggers specific G-protein coupled receptor-mediated signaling (Strub et al., 2010). Here, we found that 1,25(OH)2D3 treatment alone affects S1P1 content and counteracts its reduction promoted by A $\beta$. The expression of this S1PR subtype has been demonstrated to be diminished in AD (Ceccom et al., 2014). Therefore, the experimental evidence of a protective role of S1P signaling in $\mathrm{AD}$ animal models is consistent with the idea that the signaling pathways, triggered by S1P receptors are impaired in the AD pathology.

S1P1 triggers several Gi-mediated signaling pathways (Maceyka and Spiegel, 2014). Among them, the GaiPI3K-PKC-p38MAPK cascade is active in sensory neurons (Langeslag et al., 2014). A $\beta$ promotes ER-stress leading to activation of specific targets, including CHOPS, PERK/eIF2 $\alpha /$ ATF4 and ATF6 (De Felice and Lourenco, 2015), and stimulates p38, a member of the stressactivated MAP kinases (Kyriakis and Avruch, 2012). Notably, here, we report that active p38 MAPK is downstream of S1P1 and that 1,25(OH)2D3 as well as its structural analogue ZK191784 are able to prevent its activation. It is known from knockdown studies in rodent hippocampal neurons that ATF4 acts as an essential factor for normal synaptic plasticity and memory (Wei et al., 2015). In our study, the pharmacological inhibition of p38 MAPK as well as

1,25(OH)2D3 or ZK191784 treatment is sufficient to prevent, at least in part, A $\beta(1-42)$-induced ATF4 expression, providing the first evidence of a link between 1,25(OH)2D3 and ATF4. Therefore, the neuroprotective action of $1,25(\mathrm{OH}) 2 \mathrm{D} 3$ against $\mathrm{A} \beta$-toxicity involves the inhibition of p38 MAPK phosphorylation and downregulation of the expression of ATF4, important regulator of the physiological state of neurons.

To further study the relevance of $1,25(\mathrm{OH}) 2 \mathrm{D} 3$ treatment against $\mathrm{A} \beta$ toxicity in vivo, we infused 
aggregated $A \beta(1-42)$ directly into the hippocampus of adult rats. This experimental system, widely used to determine the neuroprotective potential of several compounds (Ryu et al., 2004; Xuan et al., 2012) offers the advantage that $A \beta(1-42)$ levels can be acutely elevated in a specific brain district, and neuronal loss occurs rapidly (within 1 to 2 weeks; Jean et al., 2015). We found that the neurotoxic effect was considerably reduced when the animals were pretreated with $1,25(\mathrm{OH})_{2} \mathrm{D}_{3}$. Indeed we observed a significant rescue of vulnerable CA1 pyramidal neurons in hormone-treated rats. Based on our in vitro findings, the most likely explanation of these data is that $1,25(\mathrm{OH}) 2 \mathrm{D} 3$ acts by activating pro-survival pathways directly in neurons. Since $A \beta$ causes neuronal loss also indirectly (via activation of glial cells), an alternative hypothesis is that $1,25(\mathrm{OH}) 2 \mathrm{D} 3$ treatment reduces pro- inflammatory pathways in microglia and astrocytes. Since SLs are mediator of inflammation processes in many conditions (Gomez-Munoz et al., 2016), $1,25(\mathrm{OH}) 2 \mathrm{D} 3$ could act through these bioactive lipids preventing a further damage in a tissue already injured by inflammation.

Adult neurogenesis allows the regeneration of certain neuronal populations in the CNS after damage (Peretto et al., 2015). In mammals, neural stem cells are mainly located within the SVZ and the SGZ zone. Hippocampal neurogenesis appears to be differentially affected during the progression of the neurogenerative diseases (Gomez-Nicola et al., 2014; Mainardi et al., 2014). Indeed, Ekonomou et al. (2015) have found a decrease in newly generated neurons in the SGZ, but not in SVZ, correlated with AD advanced stages. We have studied neurogenesis in the SVZ of mice and we have not observed an increase of neurogenesis after $A \beta(1-42)$ injection, probably because our experimental model reflects the initial step of the disease. Interestingly, we have found that 1,25(OH)2D3 increases neurogenesis only in the SGZ, but not in the SVZ of mice. Although these results might seem unexpected since 1,25(OH)2D3 usually has an antiproliferative role (Cui et al., 2007; Zhu et al., 2012), it is in agreement with Shirazi et al., (2015) which have recently reported a proliferative effect of $1,25(\mathrm{OH}) 2 \mathrm{D} 3$ on neuronal stem cells. Therefore, the effect of $1,25(\mathrm{OH}) 2 \mathrm{D} 3$ on neurogenesis appears to be complex since it may depend on the developmental and pathological stage and on the characteristics of the neurogenic niche. In fact, although embryonic and adult neurogenesis in both SGZ and SVZ share multiple common regulatory factors, several differences have been also identified in adult neurogenic niches regarding the specification of neural 
progenitors as well as internal/external stimuli (i.e. hormones/enviromental conditions) capable to modulate these processes (Ming and Song, 2011; Schoenfeld and Gould, 2013; Luzzati et al., 2014).

Other interesting finding pinpointed by our data is that $1,25(\mathrm{OH}) 2 \mathrm{D} 3$-mediated enhancement of stem/progenitor cell proliferation in the hippocampal SGZ was completely abolished by $\mathrm{A} \beta(1-42)$ oligomers intra- cerebroventricular infusion, which by itself had no significant effects on neurogenesis. Therefore, our data may indicate that $1,25(\mathrm{OH}) 2 \mathrm{D} 3$ and the toxic peptide $\mathrm{A} \beta(1-42)$ converge antagonistically on the same intracellular pathways and/or same stem cell niche or precursor cells. The maintenance of the normal functionality of the stem cell niche might be a 1,25(OH)2D3dependent event and the capability of aggregated $A \beta(1-42)$ to promote progression of the disease might include an effect that interferes with the beneficial action of the hormone in that niche.

In conclusion, the present work demonstrates that SphK/S1P1 axis is an essential effector of $1,25(\mathrm{OH}) 2 \mathrm{D} 3$ in the control of human SH-SY5Y differentiated cells survival. Similarly, the 1,25(OH)2D3 structural analogue ZK191784 mimics hormone action against A $\beta(1-42)$ peptide toxicity affecting S1P1/p38MAPK/ATF4 axis. The knowledge of the crosstalk between 1,25(OH)2D3 and SLs and the molecular mechanisms involving S1P1/p38MAPK as well as ER stress response in the neuroprotective action, could help to identify a new preventive approach in protein aggregation- based disorders. 


\section{Funding}

This work was partially supported by grants from the Italian Ministry for Education, University and Research, Rome, Italy to E.M.and M.G.-G and Fondazione Banche di Pistoia e Vignole to E.M.

\section{Disclosure}

The authors have no conflicts of interest related to the work in this article

\section{Acknowledgements}

The authors are grateful to U. Zuegel and A. Steinmeyer, Bayer Schering Pharma AG, Bayer, Berlin, Germany for kindly providing the $1,25(\mathrm{OH})_{2} \mathrm{D}_{3}$ analogues, ZK191784, ZK159222, and to Dr. Ivana Perrotta and Dr. Mirko Cecchi (University of Firenze) for experimental support. 


\section{Figure legends}

Figure 1. Effect of $A \beta$ and $1,25(\mathrm{OH})_{2} D_{3}$ on cell morphology, cell proliferation, cell viability, and apoptosis in differentiated SH-SY5Y cells.

Effect of $A \beta$ or $A \beta$ and 1,25(OH)2D3 on cell morphology (A), cell proliferation (B), cell viability $(C)$ and apoptosis (D) in differentiated SH-SY5Y cells. A. Morphological comparison between undifferentiated and differentiated SH-SY5Y cells after $1 \mu \mathrm{M}$ aggregated $\mathrm{A} \beta(1-42)(\mathrm{A} \beta)$ or unaggregated $\mathrm{A} \beta$ (vehicle) or 100 $\mathrm{nM} 1,25(\mathrm{OH}) 2 \mathrm{D} 3$ or $\mathrm{A} \beta$ and $1,25(\mathrm{OH}) 2 \mathrm{D} 3$ treatment. Cells were exposed for $16 \mathrm{~h}$ to $1,25(\mathrm{OH}) 2 \mathrm{D} 3$ and then to the amyloid peptide for the last $6 \mathrm{~h}$ incubation. Note the dramatic morphological changes in cell body dimension, neurite outgrowth and complexity $(\mathrm{bar}=30 \mu \mathrm{M})$. B. Neurite length. Cells were treated as described in A and neurite length measured as described in Methods. Mean values were obtained by averaging values from the measurement of approximately 50 neurites per well in two separate wells $(n=3$ independent experiments) ( $\mathrm{t}$-test, two-way ANOVA). Data are expressed as means \pm SEM. C. Cell number was measured by counting the cells after $0.1 \%$ Trypan Blue incubation. Data are means ( \pm S.E.M.) of $n=7$ independent experiments. D. Cell viability was determined by MTS assay in the conditions reported above and in Methods. Absorbance at $490 \mathrm{~nm}$ is reported as means ( \pm S.E.M.) of $\mathrm{n}=5$ independent

experiments (Student's $t$ test, $* \mathrm{p}<0.05$ vs vehicle, ${ }^{\S} \mathrm{p}<0.05$ vs A $\beta$ ). E. Protein expression levels of the proapoptotic factors, Bax, was evaluated by Western Blotting analysis as in Methods and $\beta$-actin content was used as loading control. Data resulting from densitometric analysis of three independent blots is reported ( \pm S.E.M. less than 15\%). F. Cell cycle analysis. SH-SY5Y cells treated with unaggregated (vehicle) or aggregated $\mathrm{A} \beta(1-42)(\mathrm{A} \beta)(6 \mathrm{~h})$ and $1,25(\mathrm{OH})_{2} \mathrm{D}_{3}$ or hormone analogue $\mathrm{ZK} 159222$ or ZK191784 alone or prior $A \beta$ plus $(24 \mathrm{~h})$ were fixed and processed with Tali ${ }^{\circ}$ Image-Based Cytometer as described in Methods. Data are reported as single dots of $n=3$ independent experiments performed in duplicate (Student's $t$ test, ${ }^{*} \mathrm{p}<0.05$ vs vehicle; ${ }^{\S} \mathrm{p}<0.05 v s \mathrm{~A} \beta$ ). 
Figure 2. Effect of $\mathrm{A} \beta(1-42)$ and $1,25(\mathrm{OH})_{2} \mathrm{D}_{3}$ on hippocampal histology in adult rats.

Hippocampal histology in representative control and aggregated $A \beta(1-42)(\mathrm{A} \beta)$-injected rats. All sections were stained with NeuN to visualize the CA1 pyramidal cell layer (Pyr). Control hippocampus (a); hippocampus injected with aggregated $A \beta(1-42)(A \beta)$ and treated with vehicle (b) or 1,25(OH)2D3 (c). Scale bar $=100 \mu \mathrm{m}$. s. o., stratum oriens; s.r., stratum radiatum. Quantification of lesion in A $\beta$ - and $1,25(\mathrm{OH}) 2 \mathrm{D} 3+\mathrm{A} \beta$-treated rats (d). Data are normalized to the average of lesion measured in animals treated with aggregated $A \beta(1-42)(A \beta, 100 \%)$ are reported as mean \pm S.E.M. (Student's t-test, $\mathrm{p}<0.001)$.

\section{Figure 3. Effect of $\mathrm{A} \beta$ and $1,25(\mathrm{OH})_{2} \mathrm{D}_{3}$ on stem/progenitor cell proliferation in the adult mouse brain}

A. Impact of $A \beta$ and 1,25(OH)2D3 on proliferation of SVZ cells. Cell counts were performed as reported in Methods. Data expressed as BrdU-positive cells $/ \mathrm{mm}^{2}$ are mean \pm S.E.M of at least four independent experiments. B. Impact of $A \beta(1-42)$ and 1,25(OH) $2 D 3$ on proliferation of subgranular zone cells. Systemic treatment with $1,25(\mathrm{OH}) 2 \mathrm{D} 3$ (but not vehicle) enhances the number of proliferating cells in the subgranular zone of dentate gyrus and its effect is abolished by treatment with aggregated A $\beta(1-42)$ $(A \beta)$. Data represent the stereological counts of BrdU-positive cells in the whole hippocampus and are expressed as mean \pm S.E.M. (two way ANOVA followed by Tukey test, $* * * p<0.001$ ).

\section{Figure 4. Sphingosine kinase activity and sphingolipid content are modulated by}

\section{$1,25(\mathrm{OH})_{2} \mathrm{D}_{3}$ and $\mathrm{A} \beta$ in differentiated $\mathrm{SH}-\mathrm{SY} 5 \mathrm{Y}$ cells}

A. SphK activity. SphK activity was determined in cell lysates $(30-50 \mu \mathrm{g})$ obtained from SH- SY5Y cells treated with unaggregated $A \beta(1-42)$ (vehicle) or aggregated $A \beta(1-42)(A \beta)$ or/and 1,25(OH)2D3 as indicated in Fig. 1. Enzyme activity is reported as percentage of control. Data are 
mean \pm SEM of at least three independent experiments performed in duplicate (Student's $t$ test, ${ }^{*} \mathrm{p}<0.05$, $\mathrm{A} \beta+1,25(\mathrm{OH}) 2 \mathrm{D} 3$ vs A $\beta$ ). B-C. Sphingolipid determination. Differentiated SH-SY5Y cells were incubated for $24 \mathrm{~h}$ with $\left[{ }^{3} \mathrm{H}\right]$ serine and then treated with unaggregated or aggregated $\mathrm{A} \beta(1-42)$ or/and 1,25(OH)2D3. Sphingosine 1-phosphate (S1P) and ceramide (Cer) were extracted as reported in Methods and $\left[{ }^{3} \mathrm{H}\right]$-radiolabelled-Cer and $\left[{ }^{3} \mathrm{H}\right]$-radiolabelled-S1P quantified as in Methods. SLs content on total radiolabeled $\left[{ }^{3} \mathrm{H}\right]$ lipids is reported as mean \pm S.E.M. of at least three independent experiments (Student's $t$ test, $* \mathrm{p}<0.05$ vs vehicle).

\section{Figure. $51,25(\mathrm{OH})_{2} \mathrm{D}_{3}$ exerts its neuroprotective action through $\mathrm{S} 1 \mathrm{P} / \mathrm{S} 1 \mathrm{P} 1$ axis}

A-B. S1P expression. Cell lysates $(20-30 \mu \mathrm{g})$ obtained from differentiated SH-SY5Y cells treated with unaggregated $A \beta$ (vehicle) or aggregated $A \beta(1-42)(A \beta)$ or/and 1,25(OH)2D3 were separated by SDSPAGE. Protein blotted to nitrocellulose membrane were then immunodetected using specific anti-S1P1 antibody. $\beta$-actin was used as loading control. Data resulting from densitometric analysis of S1P1 and $\beta$ actin were normalized. A blot of a representative experiments is reported. Data are means \pm SEM of at least three independent experiments. C. Quantification of SIP1 mRNA expression by Real Time PCR. Differentiated SH-SY5Y cells treated w i t h unaggregated $A \beta$ (vehicle) or aggregated $A \beta(1-42)(A \beta)$ or/and 1,25(OH)2D3 were used for RNA preparation and reverse transcription as described in Methods. Data are reported as relative fold of expression $\pm \mathrm{SD}$. ${ }^{*} \mathrm{p}<0.05$ vs vehicle, $\S \mathrm{p}<0.05$ vs $\mathrm{A} \beta$

Figure 6. Effect of S1P inhibition and 1,25(OH $)_{2} \mathrm{D}_{3}$ on p38 MAPK levels in SH-SY5Y cells.

A-D Phospho-p38 MAPK expression. Protein expression levels of phospho-p38 MAPK (p-p38) was determined by Western blotting as described in Methods and Fig. 5. Cell lysates (20-30 $\mu \mathrm{g})$ obtained from differentiated SH-SY5Y cells treated with vehicle or S1P antagonist W146 $(2 \mu \mathrm{M})$ or 1,25(OH)2D3 (100 $\mathrm{nM})$ for $24 \mathrm{~h}$ and W146 and S1P agonist SEW2871 $(2 \mu \mathrm{M})$ for 10 min or pre-treated with 1,25(OH)2D3 
or ZK191784 for $16 \mathrm{~h}$ and then incubated with $A \beta$ for the last $6 \mathrm{~h}$. In some experiments cells were treated with 1,25(OH)2D3 or ZK191784 for $8 \mathrm{~h}$ before the addition of tunicamycin (TUN) for $16 \mathrm{~h}$. Proteins were loaded onto SDS-PAGE and protein immunodetected by specific antibodies anti-phospho p38. $\beta$-actin was used as loading control. Data resulting from densitometric analysis of at least $n=3$ independent experiments is shown in the graph (mean \pm S.E.M.). (Student's $t$ test, C.* $\mathrm{p}<0.05$ vs vehicle, $\# \mathrm{p}<0.05$ vs 1,25(OH)2D3; D. ${ }^{*} \mathrm{p}<0.05$ vs vehicle, $\# \mathrm{p}<0.05$ vs TUN, ${ }^{\S} \mathrm{p}<0.05$ vs $\left.\mathrm{A} \beta\right)$.

Figure 7. Effect of $1,25(\mathrm{OH})_{2} \mathrm{D}_{3}$ and its analog ZK191784 on transcriptional factor ATF4 protein expression in the presence of $A \beta$ or Tunicamycin

A. Cell lysate $(20-30 \mu \mathrm{g})$ obtained from differentiated SH-SY5Y cells treated in the absence or in the presence of $1,25(\mathrm{OH}) 2 \mathrm{D} 3$ or $\mathrm{ZK} 191784$ prior to aggregated $\mathrm{A} \beta(1-42)(\mathrm{A} \beta)$ or unaggregated $\mathrm{A} \beta(1-42)$ (vehicle) for $6 \mathrm{~h}$ or Tunicamycin (TUN, $2 \mu \mathrm{M})$ for $16 \mathrm{~h}$ were loaded onto SDS-PAGE and protein immunodetected by specific antibodies. $\beta$-actin was used as loading control. Blot shown is representative. Data resulting from densitometric analysis of at least $n=3$ independent experiments is shown in the graph (mean $\pm \mathrm{SEM}$ ). (Student's $t$ test, $\mathrm{C}^{*} \mathrm{p}<0.05$ vs specific control, $\# \mathrm{p}<0.05$ vs TUN). 


\section{References}

Airola, M.V., Hannun, Y.A., 2013. Sphingolipid metabolism and neutral sphingomyelinases. Handb. Exp. Pharmacol. 215, 57-76. doi: 10.1007/978-3-7091-1368-43.

Amtul, Z., Nikolova, S., Gao, L., Keeley, R.J., Bechberger, J.F., Fisher, A.L., Bartha, R., Munoz, D.G., McDonald, R.J., Naus, C.C., Wojtowicz, J.M., Hachinski, V., Cechetto, D.F., 2014. Comorbid A $\beta$ toxicity and stroke: hippocampal atrophy, pathology, and cognitive deficit. Neurobiol. Aging 35, 1605-1614. doi: 10.1016/j.neurobiolaging.2014.01.005

Annweiler, C., Karras, S.N., Anagnostis, P., Beauchet, O., 2014. Vitamin D supplements: a novel therapeutic approach for Alzheimer patients. Front. Pharmacol. 5:6. doi: 10.3389/fphar.2014.00006

Annweiler, C., Dursun, E., Féron „F., Gezen-Ak, D., Kalueff, A.V., Littlejohns, T., Llewellyn, D.J., Millet, P., Scott, T., Tucker, K.L., Yilmazer, S., Beauchet, O., 2015.'Vitamin D and cognition in older adults': updated international recommendations. J. Intern. Med. 277(1), 45-57. doi: 10.1111/joim.12279

Antonucci, F., Cerri C., Maya Vetencourt, J.F., Caleo, M., 2010. Acute neuroprotection by the synaptic blocker botulinum neurotoxin $\mathrm{E}$ in a rat model of focal cerebral ischaemia. Neuroscience. 169(1), 395-401. doi:10.1016/j.neuroscience.2010.04.059

Berridge, M.J., 2015. Vitamin D cell signaling in health and disease. Biochem. Biophys. Res. Commun. 460(1), 53-71. doi: 10.1016/j.bbrc.2015.01.008

Bini, F., Frati, A., Garcia-Gil, M., Battistini, C., Granado, M., Martinesi, M., Mainardi, M., Vannini, E., Luzzati, F., Caleo, M., Peretto, P., Gomez-Muñoz, A., Meacci, E., 2012. New signalling pathway involved in the anti-proliferative action of vitamin D3 and its analogues in human neuroblastoma cells. A role for 
ceramide kinase. Neuropharmacology. 63(4),524-37. doi:

10.1016/j.neuropharm.2012.04.026

Caleo, M., Restani, L., Vannini, E., Siskova, Z., Al-Malki, H., Morgan, R., O'Connor, V., Perry, V.H.

2012. The role of activity in synaptic degeneration in a protein misfolding disease, prion disease. PLoS One. 7(7):e41182. doi: 10.1371/journal.pone.0041182

Caleo, M., Restani, L., Perry, V.H. 2013. Silencing synapses: a route to understanding synapse degeneration in chronic neurodegenerative disease. Prion. 7(2),147-50. doi: 10.4161/pri.23327

Campioni, S., et al. 2010. A causative link between the structure of aberrant protein oligomers and their toxicity. Nat.Chem. Biol. 6:140-147. doi: 10.1038/nchembio.283.

Ceccom, J., et al. 2014. Reduced sphingosine kinase-1 and enhanced sphingosine 1-phosphate lyase expression demonstrate deregulated sphingosine 1-phosphate signaling in Alzheimer's disease. Acta Neuropathol. Commun.2:12. doi: 10.1186/2051-5960-2-12

Chow, E.C., Durk, M.R., Cummins, C.L., Pang, K.S., 2011. 1Alpha,25-dihydroxyvitamin D3 up-regulates Pglycoprotein via the vitamin D receptor and not farnesoid $\mathrm{X}$ receptor in both $\mathrm{fxr}(-/-)$ and $\mathrm{fxr}(+/+)$ mice and increased renal and brain efflux of digoxin in mice in vivo. J. Pharmacol. Exp. Ther. 337(3), 846-859. doi: 10.1124/jpet.111.179101

Couttas, T.A., et al. 2014. Loss of the neuroprotective factor Sphingosine 1-phosphate early in Alzheimer's disease pathogenesis. Acta Neuropathol. Commun. Jan 23;2:9. doi: 10.1186/2051$5960-2-9$ 
Costantin, L., Bozzi, Y., Richichi, C., Viegi, A., Antonucci, F., Funicello, M., Gobbi, M., Mennini, T., Rossetto, O., Montecucco, C., Maffei, L., Vezzani, A., Caleo, M., 2005. Antiepileptic effects of botulinum neurotoxin E. J. Neurosci. 25(8),1943-1951. doi: 10.1523/JNEUROSCI.440204.2005

Cui, X., McGrath, J.J., Burne, T.H., Mackay-Sim, A., Eyles, D.W., 2007. Maternal vitamin D depletion alters neurogenesis in the developing rat brain. Int. J. Dev. Neurosci.25(4),227-232. doi: 10.1016/j.ijdevneu.2007.03.006

Cuvillier, O., Pirianov, G., Kleuser, B., Vanek, P.G., Coso, O.A., Gutkind, S., Spiegel, S., 1996. Suppression of ceramide-mediated programmed cell death by sphingosine-1-phosphate. Nature. 381, 800-803. doi:10.1038/381800a0

Dahlgren, K.N., Manelli, A.M., Stine, W.B. Jr., Baker, L.K., Krafft, G.A., LaDu, M.J., 2002. Oligomeric and fibrillar species of amyloid-beta peptides differentially affect neuronal viability. J. Biol. Chem. 277(35),32046-32053. doi: 10.1074/jbc.M201750200

De Felice, F.G., Lourenco, M.V., 2015. Brain metabolic stress and neuroinflammation at the basis of cognitive impairment in Alzheimer's disease. Front. Aging Neurosci. 7:94. doi: 10.3389/fnagi.2015.00094

De Palma, C., Meacci, E., Perrotta, C., Bruni, P., Clementi, E., 2006. Endothelial nitric oxide synthase activation by tumor necrosis factor alpha through neutral sphingomyelinase 2, sphingosine kinase 1, and sphingosine 1 phosphate receptors: a novel pathway relevant to the pathophysiology of endothelium. Arterioscler. Thromb. Vasc. Biol. 26(1), 99-105. doi:

10.1161/01.ATV.0000194074.59584.42

DeLuca, G.C., Kimball, S.M., Kolasinski, J., Ramagopalan, S.V., Ebers, G.C., 2013. Review: the role of 
vitamin D in nervous system health and disease. Neuropathol. Appl. Neurobiol. 39(5), 458-

84. doi: $10.1111 /$ nan. 12020

Ekonomou, A., Savva, G.M., Brayne, C., Forster, G., Francis, P.T., Johnson, M., Perry, E.K., Attems, J., Somani, A., Minger, S.L., Ballard, C.G., 2015. Medical Research Council Cognitive

Function and Ageing Neuropathology Study. Stage-specific changes in neurogenic and glial markers in Alzheimer's disease. Biol. Psychiatry. 77(8),711-719. doi:

10.1016/j.biopsych.2014.05.021

Eyles, D.W., Burne, T.H., McGrath, J.J., 2013. Vitamin D, effects on brain development, adult brain function and the links between low levels of vitamin D and neuropsychiatric disease. Front. Neuroendocrinol. 34(1),47-64. doi:10.1016/j.yfrne.2012.07.001

Frati, A., Ricci, B., Pierucci, F., Nistri, S., Bani, D., Meacci, E., 2015. Role of sphingosine kinase/S1P axis in ECM remodeling of cardiac cells elicited by relaxin. Mol. Endocrinol. 29(1),

53-67. doi: 10.1210/me.2014-1201

Ghasemi, R., Dargahi, L., Ahmadiani, A., 2016. Integrated sphingosine-1 phosphate signaling in the central nervous system: From physiological equilibrium to pathological damage. Pharmacol. Res. 104, 156-164. doi: 10.1016/j.phrs.2015.11.006

Gomez-Brouchet, A., Pchejetski, D., Brizuela, L., Garcia, V., Altié, M.F., Maddelein, M.L., Delisle, M.B., Cuvillier, O., 2007. Critical role for sphingosine kinase-1 in regulating survival of neuroblastoma cells exposed to amyloid-beta peptide. Mol. Pharmacol. 72(2), 341-349. doi:

$10.1124 / \mathrm{mol} .106 .03378$

Gomez-Muñoz, A., Presa, N., Gomez-Larrauri, A., Rivera, I.G., Trueba, M., Ordoñez, M., 2016. Control

of inflammatory responses by ceramide, sphingosine 1-phosphate and ceramide 1- phosphate. Prog. Lipid Res. 61, 51-62. doi:10.1016/j.plipres.2015.09.002 
Gomez-Nicola, D., Suzzi, S., Vargas-Caballero, M., Fransen, N.L., Al-Malki, H', Cebrian-Silla, A', GarciaVerdugo, J.M., Riecken, K, Fehse, B', Perry, V.H., 2014. Temporal dynamics of hippocampal neurogenesis in chronic neurodegeneration. Brain. 137, 2312-2328. doi: 10.1093/brain/awu155

Grimm, M.O., Zimmer, V.C., Lehmann, J., Grimm, H.S., Hartmann, T., 2013. The impact of cholesterol, DHA, and sphingolipids on Alzheimer's disease. Biomed. Res. Int. 2013:814390. doi:

$10.1155 / 2013 / 814390$

Grimm, M.O., Lehmann, J., Mett, J., Zimmer, V.C., Grösgen, S., Stahlmann, C.P., Hundsdörfer, B., Haupenthal, V.J., Rothhaar, T.L., Herr, C., Bals, R., Grimm, H.S., Hartmann, T., 2014. Impact of Vitamin D on amyloid precursor protein processing and amyloid- $\beta$ peptide degradation in Alzheimer's disease. Neurodegener, Dis.13(2-3), 75-81. doi:10.1159/000355462

Haughey, N.J., 2010. Sphingolipids in neurodegeneration. Neuromolecular Med. 12(4), 301-305. doi: $10.1007 / \mathrm{s} 12017-010-8135-5$

He, X., Huang, Y., Li, B., Gong, C.X., Schuchman, E.H., 2010. Deregulation of sphingolipid metabolism in Alzheimer's disease. Neurobiol. Aging. 31(3), 398-408. doi:10.1016/j.neurobiolaging.2008.05.010

Jean, Y.Y., Baleriola, J., Fà, M., Hengst, U., Troy, C.M., 2015. Stereotaxic Infusion of Oligomeric Amyloid-beta into the Mouse Hippocampus. J. Vis. Exp. (100):e52805. doi: 10.3791/52805

Kyriakis, J.M., Avruch, J., 2012. Mammalian MAPK signal transduction pathways activated by stress and inflammation: a 10-year update. Physiol. Rev. 92(2), 689-737. doi: 10.1152/physrev.00028.2011 
Łaczmański, Ł., Jakubik, M., Bednarek-Tupikowska,G., Rymaszewska, J., Słoka, N., Lwow, F. Vitamin D receptor gene polymorphisms in Alzheimer's disease patients. 2015. Exp. Gerontol. 69, 142-147. doi: 10.1016/j.exger.2015.06.012

Landel, V., Annweiler, C., Millet, P., Morello, M., Féron, F. 2016. Vitamin D, Cognition, and Alzheimer's Disease: The Therapeutic Benefit is in the D-Tails. J Alzheimers Dis. May 11. [Epub ahead of print] doi: 10.3233/JAD-150943

Langeslag, M., Quarta, S., Leitner, M.G., Kress, M., Mair, N. 2014. Sphingosine 1-phosphate to p38 signaling via S1P1 receptor and Gai/o evokes augmentation of capsaicin-induced ionic currents in mouse sensory neurons. Mol. Pain. 10:74. doi: 10.1186/1744-8069-10-74

Luzzati, F., Nato, G., Oboti, L., Vigna, E., Rolando, C., Armentano, M., Bonfanti, L., Fasolo, A., Peretto, P. 2014 Quiescent neuronal progenitors are activated in the juvenile guinea pig lateral striatum and give rise to transient neurons. Development. 141(21):4065-75. doi: 10.1242/dev.107987

Maceyka, M., Spiegel, S., 2014. Sphingolipid metabolites in inflammatory disease. Nature. 510,58-67. doi: 10.1038/nature13475

Mainardi, M., Di Garbo, A., Caleo, M., Berardi, N., Sale, A., Maffei, L. 2014 Environmental enrichment strengthens corticocortical interactions and reduces amyloid- $\beta$ oligomers in aged mice. Front Aging Neurosci. 6:1. doi: 10.3389/fnagi.2014.00001

Meacci, E., Bini, F., Sassoli, C., Martinesi, M., Squecco, R., Chellini, F., Zecchi-Orlandini, S., Francini, F., Formigli, L., 2010. Functional interaction between TRPC1 channel and connexin-43 protein: a novel pathway underlying S1P action on skeletal myogenesis. Cell. Mol. Life Sci. 
Milstien, S., Gude, D., Spiegel, S., 2007. Sphingosine 1-phosphate in neural signaling and function. Acta Paediatr. 96, 40-43. doi: 10.1111/j.1651-2227.2007.00206.x

Ming, G.L., Song, H., 2011. Adult neurogenesis in the mammalian brain: significant answers and significant questions. Neuron. 70(4), 687-702. doi: 10.1016/j.neuron.2011.05.001

Mizugishi, K., Yamashita, T., Olivera, A., Miller, G.F., Spiegel, S., Proia, R.L., 2005. Essential role for sphingosine kinases in neural and vascular development. Mol. Cell Biol. 25(24), 11113-

11121

Mizuno, S., Ogishima, S., Kitatani, K., Kikuchi, M., Tanaka, H., Yaegashi, N., Nakaya, J., 2016. Network Analysis of a Comprehensive Knowledge Repository Reveals a Dual Role for Ceramide in Alzheimer's Disease. PLoS One. 11(2):e0148431. doi:10.1371/journal.pone.0148431

Oboti, L., Savalli, G., Giachino, C., De Marchis, S., Panzica ,G.C., Fasolo, A., Peretto, P. 2009. Integration and sensory experience-dependent survival of newly-generated neurons in the accessory olfactory bulb of female mice. Eur. J. Neurosci. 29(4),679-692. doi: 10.1111/j.1460-9568.2009.06614.x

Pasini,S., Corona, C., Liu, J., Greene, L.A., Shelanski, M.L., 2015. Specific downregulation of hippocampal ATF4 reveals a necessary role in synaptic plasticity and memory. Cell Rep. 11(2), 183-191. doi: 10.1016/j.celrep.2015.03.025

Peretto, P., Bonfanti, L. 2015 Adult neurogenesis 20 years later: physiological function vs. brain repair. Front Neurosci. 9:71. doi: 10.3389/fnins.2015.00071

Pierucci, F., Frati, A., Squecco, R., Lenci, E., Vicenti, C., Slavik, J., Francini, F., Machala, M., Meacci, E., 
2016. Non-dioxin-like organic toxicant PCB153 modulates sphingolipid metabolism in liver progenitor cells: its role in Cx43-formed gap junction impairment. Arch. Toxicol. Jun 18. [Epub ahead of print] doi:10.1007/s00204-016-1750-7

Puglielli, L., Ellis, B.C., Saunders, A.J., Kovacs, D.M., 2003. Ceramide stabilizes beta-site amyloid precursor protein-cleaving enzyme 1 and promotes amyloid beta-peptide biogenesis. J. Biol. Chem. 278(22), 19777-19783. doi: 10.1074/jbc.M300466200

Pyne, S., Adams, D.R., Pyne, N.J., 2016. Sphingosine 1-phosphate and sphingosine kinases in health and disease: Recent advances. Prog. Lipid Res. 62, 93-106. doi: 10.1016/j.plipres.2016.03.001

Remple, K., Stone, L. 2011., Assessment of GFP expression and viability using the tali image- based cytometer. J. Vis. Exp. 17,3659. doi: 10.3791/3659

Rossi, C., Angelucci, A., Costantin, L., Braschi, C., Mazzantini, M., Babbini, F., Fabbri, M.E., Tessarollo, L., Maffei, L., Berardi, N., Caleo, M., 2006. Brain-derived neurotrophic factor (BDNF) is required for the enhancement of hippocampal neurogenesis following environmental enrichment. Eur. J. Neurosci .24, 1850-1856. doi: 10.1111/j.1460-9568.2006.05059.x

Ryu, J.K., Franciosi, S., Sattayaprasert, P., Kim, S.U., McLarnon, J.G., 2004. Minocycline inhibits neuronal death and glial activation induced by beta-amyloid peptide in rat hippocampus. Glia. 48(1), 85-90. doi: 10.1002/glia.20051

Sassoli, C., Formigli, L., Bini, F., Tani, A., Squecco, R., Battistini,C., Zecchi-Orlandini, S., Francini, F., Meacci, E., 2011. Effects of S1P on skeletal muscle repair/regeneration during eccentric contraction. J. Cell. Mol. Med. 15(11), 2498-2511. doi: 10.1111/j.1582- 
Schoenfeld, T.J., Gould, E., 2012. Stress, stress hormones, and adult neurogenesis. Exp. Neurol. 233(1),12-21. doi: 10.1016/j.expneurol.2011.01.008

Selkoe, D.J., Hardy, J., 2016. The amyloid hypothesis of Alzheimer's disease at 25 years. EMBO Mol. Med. 8(6), 595-608. doi: 10.15252/emmm.201606210

Shirazi, H.A., Rasouli, J., Ciric, B, Rostami, A., Zhang, G.X., 2015. 1,25-Dihydroxyvitamin D3 enhances neural stem cell proliferation and oligodendrocyte differentiation. Exp. Mol. Pathol. 98(2), 240-245. doi: 10.1016/j.yexmp.2015.02.004

Squecco, R., Sassoli, C., Nuti, F., Martinesi, M., Chellini, F., Nosi, D., Zecchi-Orlandini, S., Francini, F., Formigli, L., Meacci, E., 2006. Sphingosine 1-phosphate induces myoblast differentiation through Cx43 protein expression: a role for a gap junction-dependent and - independent function. Mol. Biol. Cell. 17(11), 4896-4910. doi: 10.1091/mbc.E06-03-0243

Stepanichev, M.Y., Moiseeva, Y.V., Lazareva, N.A., Onufriev, M.V., Gulyaeva, N.V., 2003. Single intracerebroventricular administration of amyloid-beta (25-35) peptide induces impairment in short-term rather than long-term memory in rats. Brain Re Bull. 61(2), 197-205. doi: $10.1016 / \mathrm{S} 0361-9230(03) 00118-7$

Strub, G.M., Maceyka, M., Hait, N.C., Milstien, S., Spiegel, S., 2010. Extracellular and intracellular actions of sphingosine-1-phosphate. Adv. Exp. Med. Biol.688, 141-55. doi: 10.1007/978-14419-6741-1_10

Sun, A., Liu, M., Nguyen, X.V., Bing, G., 2003. P38 MAP kinase is activated at early stages in Alzheimer's disease brain. Exp. Neurol. 183(2), 394-405. doi:10.1016/S0014-4886(03)00180-8 
Takasugi, N., Sasaki, T., Ebinuma, I., Osawa, S., Isshiki, H., Takeo, K., Tomita, T., Iwatsubo, T., 2013. FTY720/fingolimod, a sphingosine analogue, reduces amyloid- $\beta$ production in neurons. PLoS One. 8(5):e64050. doi:10.1371/journal.pone.0064050

Vieth, R., Kooh, S.W., Balfe, J.W., Rawlins, M., Tinmouth, W.W., 1990. Tracer kinetics and actions of oral and intraperitoneal 1,25-dihydroxyvitamin D3 administration in rats. Kidney Int. 38(5), 857-861. doi:10.1038/ki.1990.282

Villette, V., Poindessous-Jazat, F., Bellessort, B., Roullot, E., Peterschmitt, Y., Epelbaum, J., Stéphan, A., Dutar, P., 2012. A new neuronal target for $\beta$-amyloid peptide in the rat hippocampus. Neurobiol. Aging 33(6),1126.e1-14. doi: 10.1016/j.neurobiolaging.2011.11.024

Walter, J., van Echten-Deckert, G., 2013. Cross-talk of membrane-lipids and Alzheimer-related proteins. Cross-talk of membrane lipids and Alzheimer-related proteins. Mol. Neurodegener. 8, 34. doi: $10.1186 / 1750-1326-8-34$

Wei, N., Zhu, L.Q., Liu, D., 2015. ATF4: a Novel Potential Therapeutic Target for Alzheimer's Disease. Mol. Neurobiol. 52(3), 1765-1770. doi:10.1007/s12035-014-8970-8

Xuan, A., Long, D., Li, J., Ji, W., Zhang, M., Hong, L., Liu, J., 2012. Hydrogen sulphide attenuates spatial memory impairment and hippocampal neuroinflammation in $\beta$-amyloid rat model of Alzheimer's disease. J. Neuroinflammation. 9,202. doi: 10.1186/1742-2094-9-202

Zhang, Y., Yu, Q., Lai, T.B., Yang, Y., Li, G., Sun, S.G., 2013. Effects of small interfering RNA targeting sphingosine kinase-1 gene on the animal model of Alzheimer's disease. J. Huazhong Univ. Sci. Technolog. 
Med. Sci. 33(3), 427-432. doi: 10.1007/s11596-013-1136-5

Zhu, Y., Zhou, R., Yang, R., Zhang, Z., Bai, Y., Chang, F., Li, L., Sokabe, M., Goltzman, D., Miao, D., Chen, L., 2012. Abnormal neurogenesis in the dentate gyrus of adult mice lacking 1,25-dihydroxy vitamin $\quad$ D3 $\quad(1,25-(\mathrm{OH}) 2 \quad$ D3). Hippocampus. 22(3), 421-433. doi: 10.1002/hipo.209 


\section{Table 1}

\begin{tabular}{|l|c|c|} 
& S1P/ Cer & \\
\hline vehicle & 2.20 & \\
\hline $\mathbf{A} \beta$ & 0.36 & $-84 \%$ \\
\hline $\mathbf{1 , 2 5 ( O H})_{2} \mathbf{D}_{3}$ & 1.05 & \\
\hline $\begin{array}{c}\mathbf{A} \beta+ \\
\mathbf{1 , 2 5}(\mathrm{OH})_{2} \mathbf{D}_{3}\end{array}$ & $1.35^{*}$ & $-59 \%$ \\
\hline
\end{tabular}

Ratio between the content of prosurvival factor, S1P, and the proapoptotic factor, ceramide. 


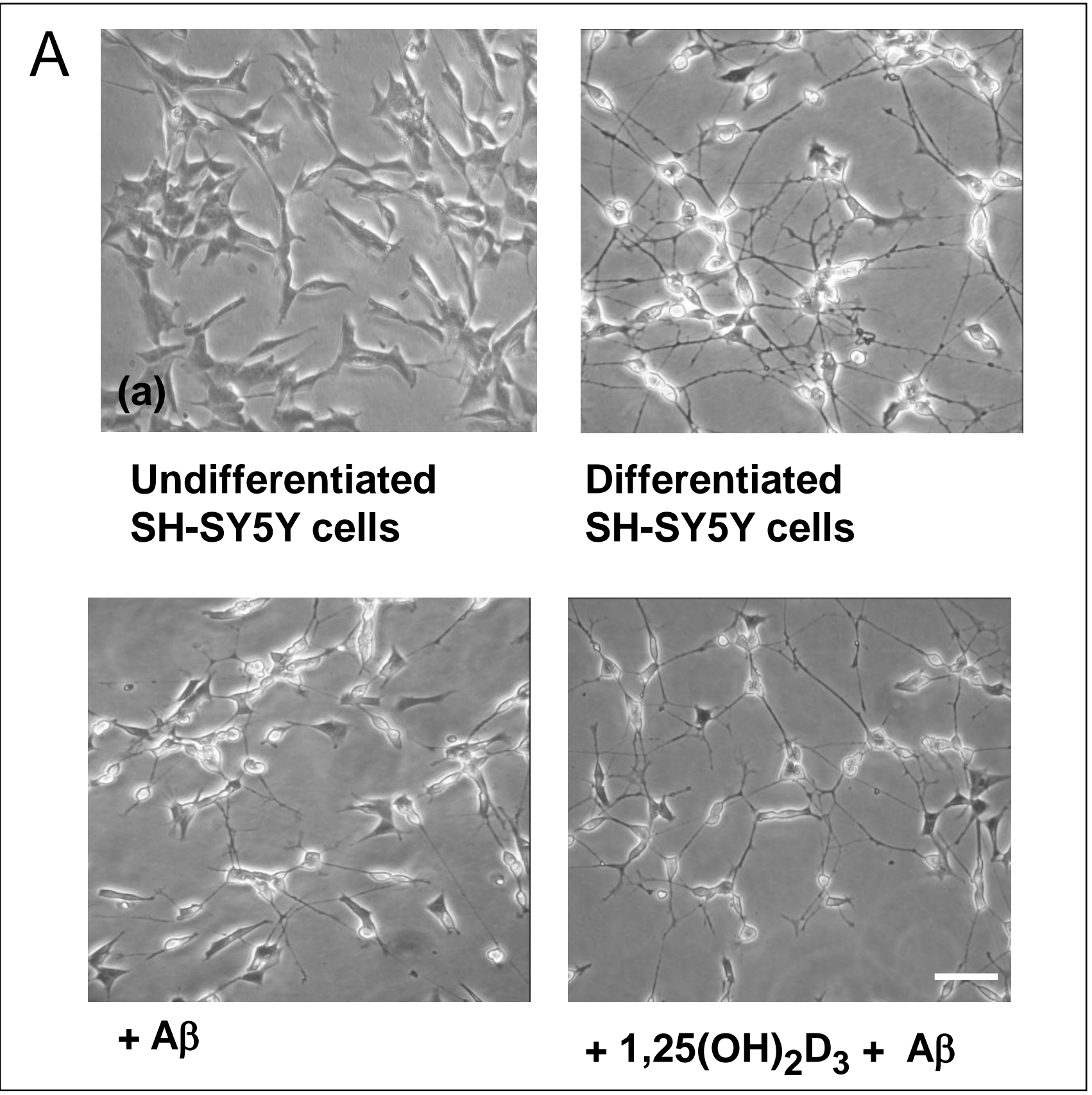

Fig $1 \mathrm{~A}$ 
B

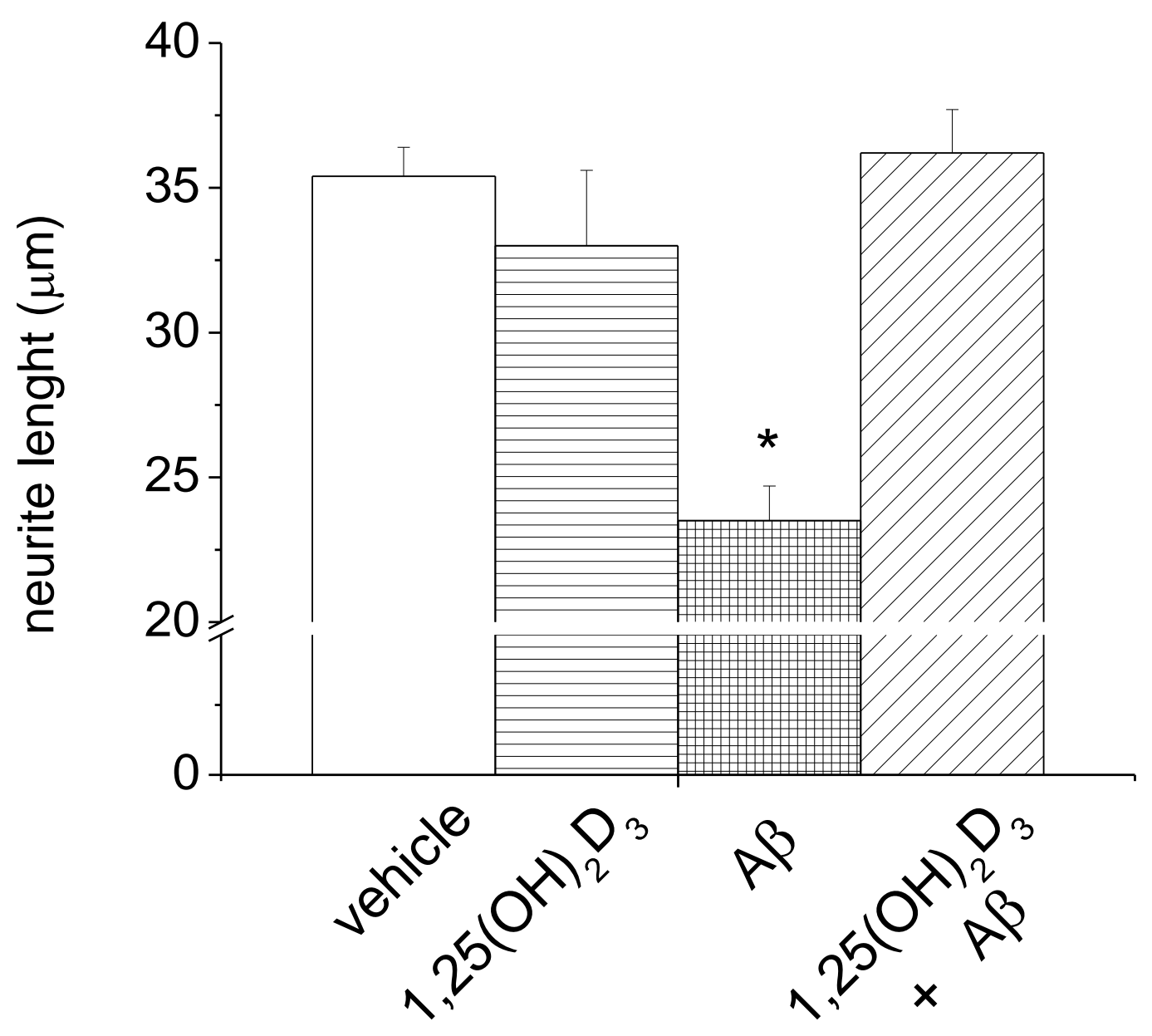

Fig 1B 


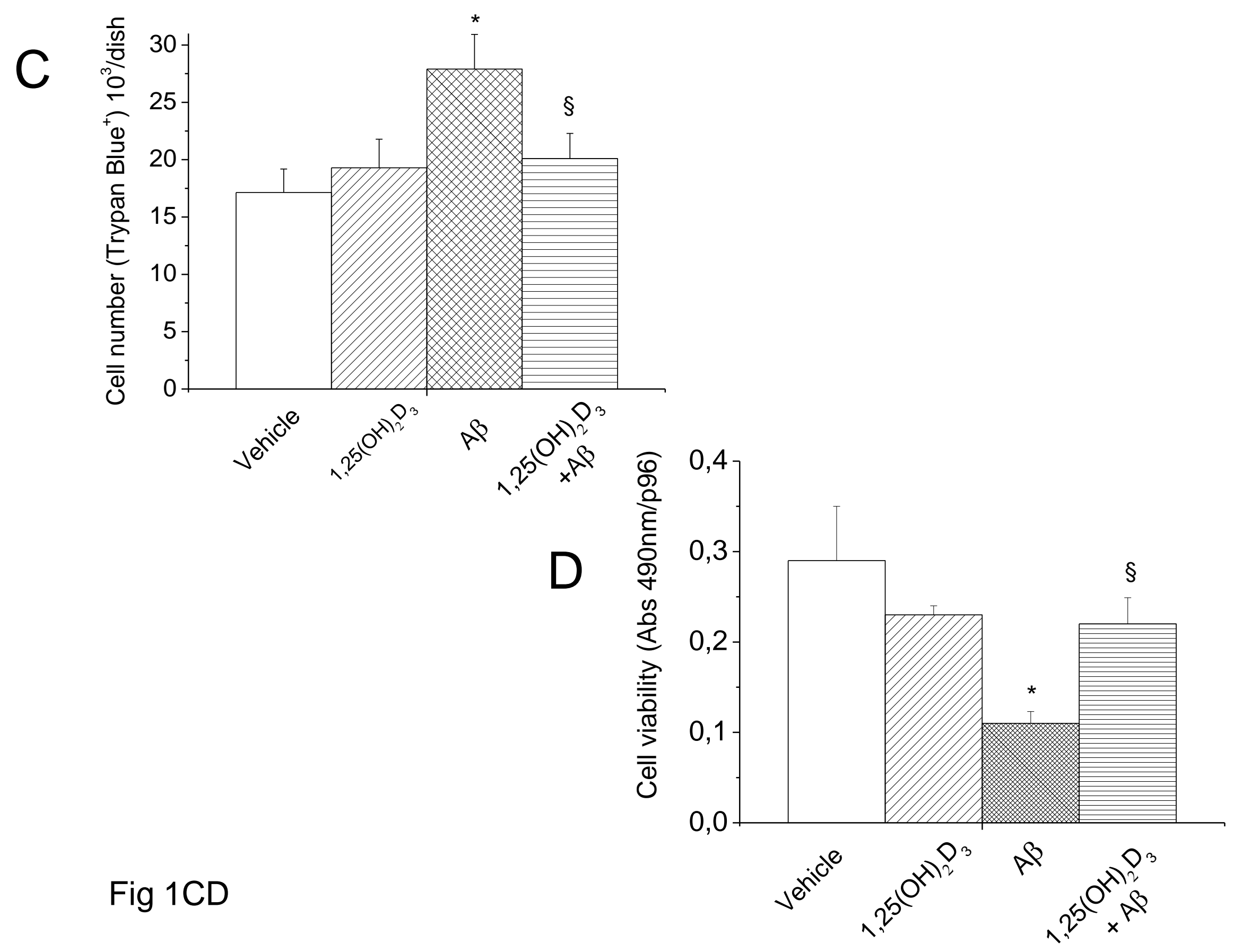




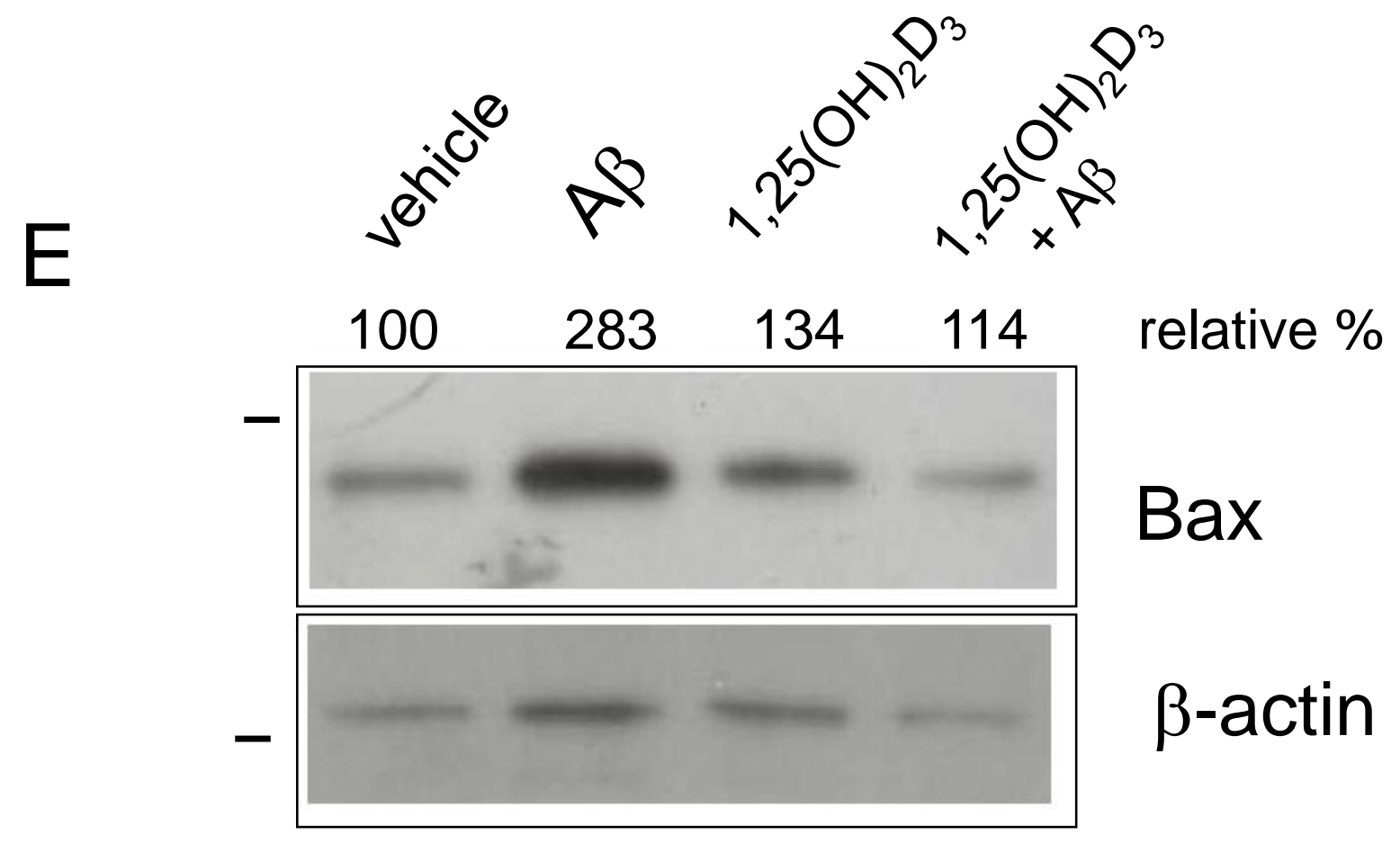

Fig 1E 
F
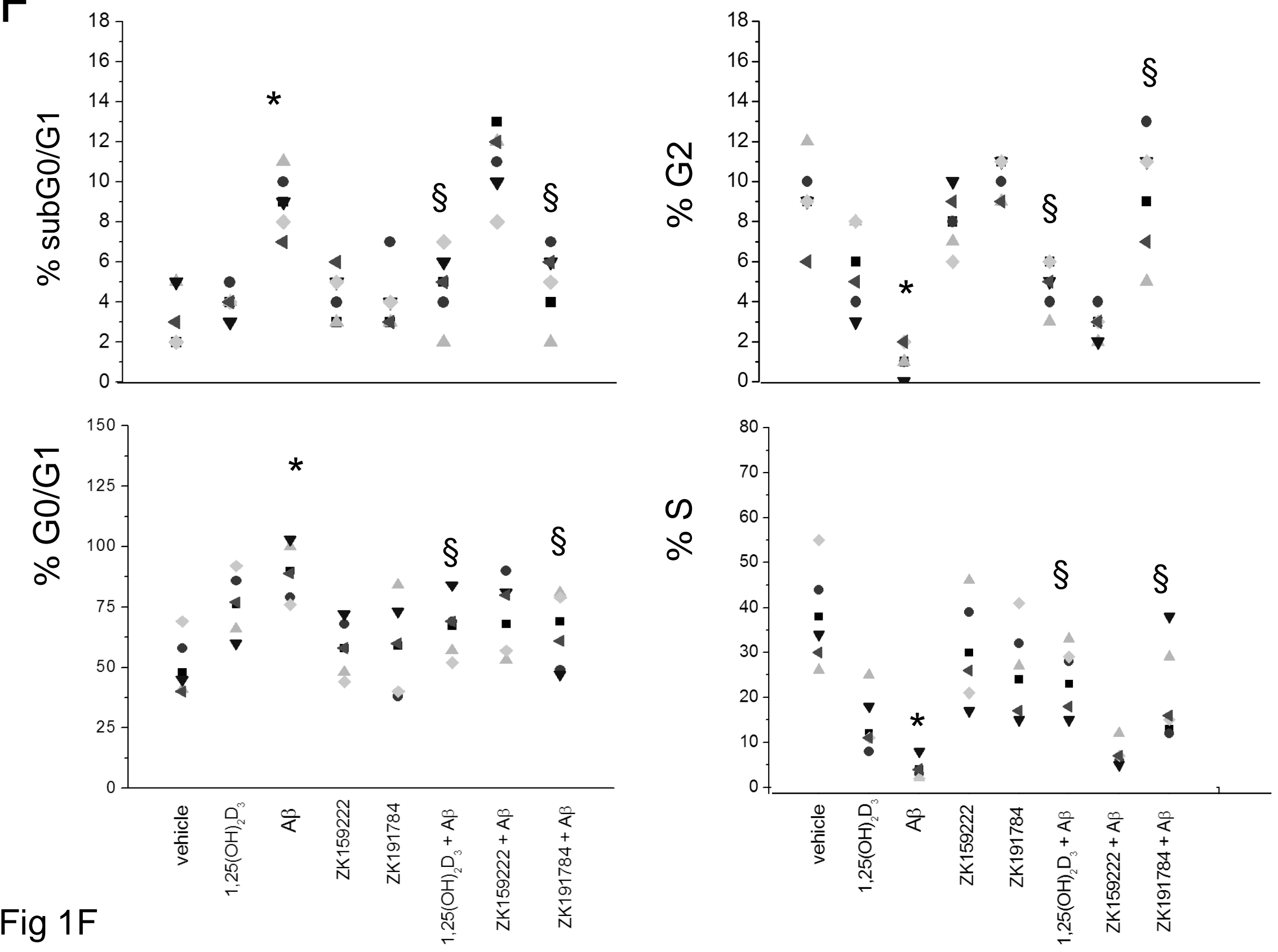


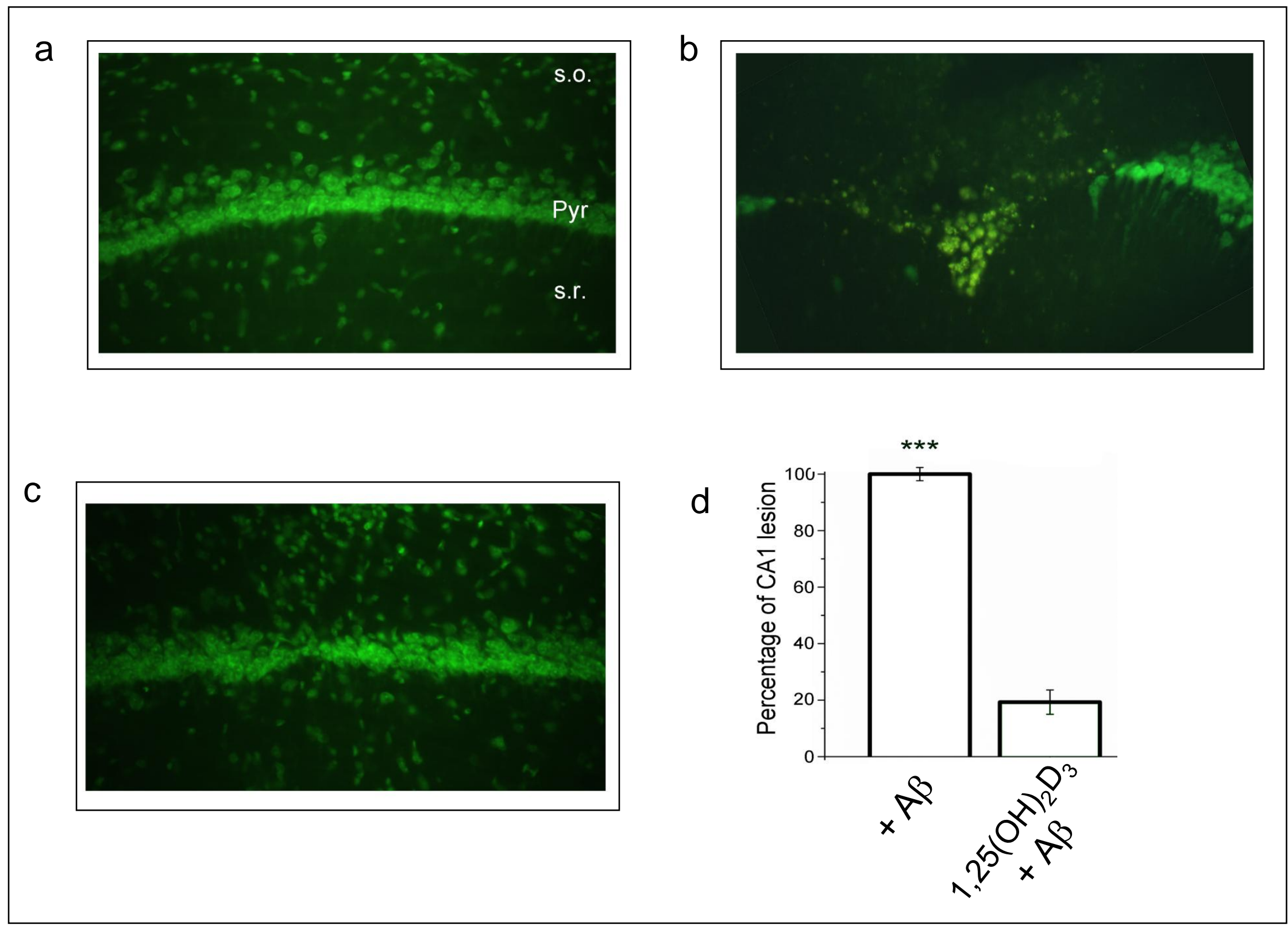

Fig 2 


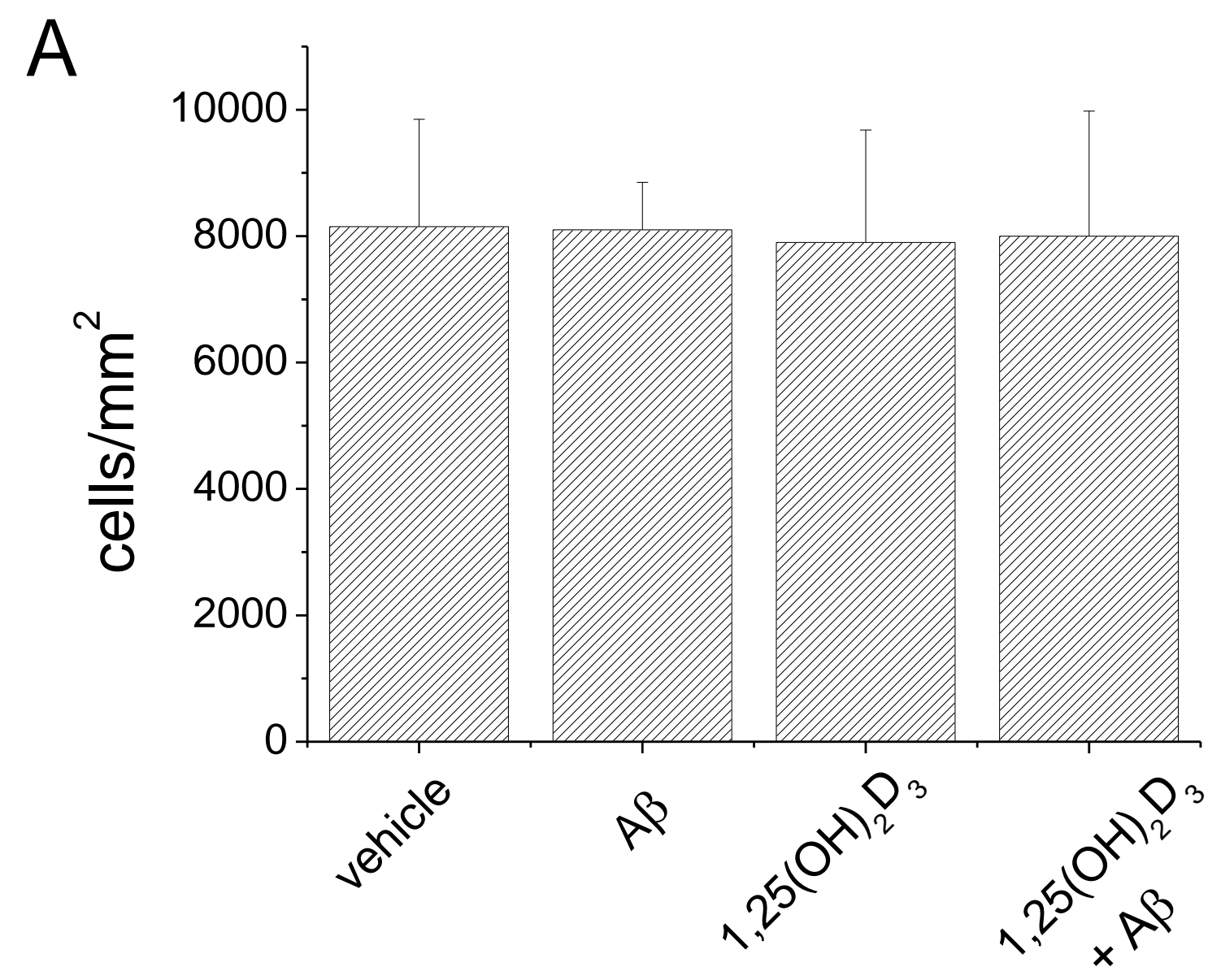

Fig. 3A 


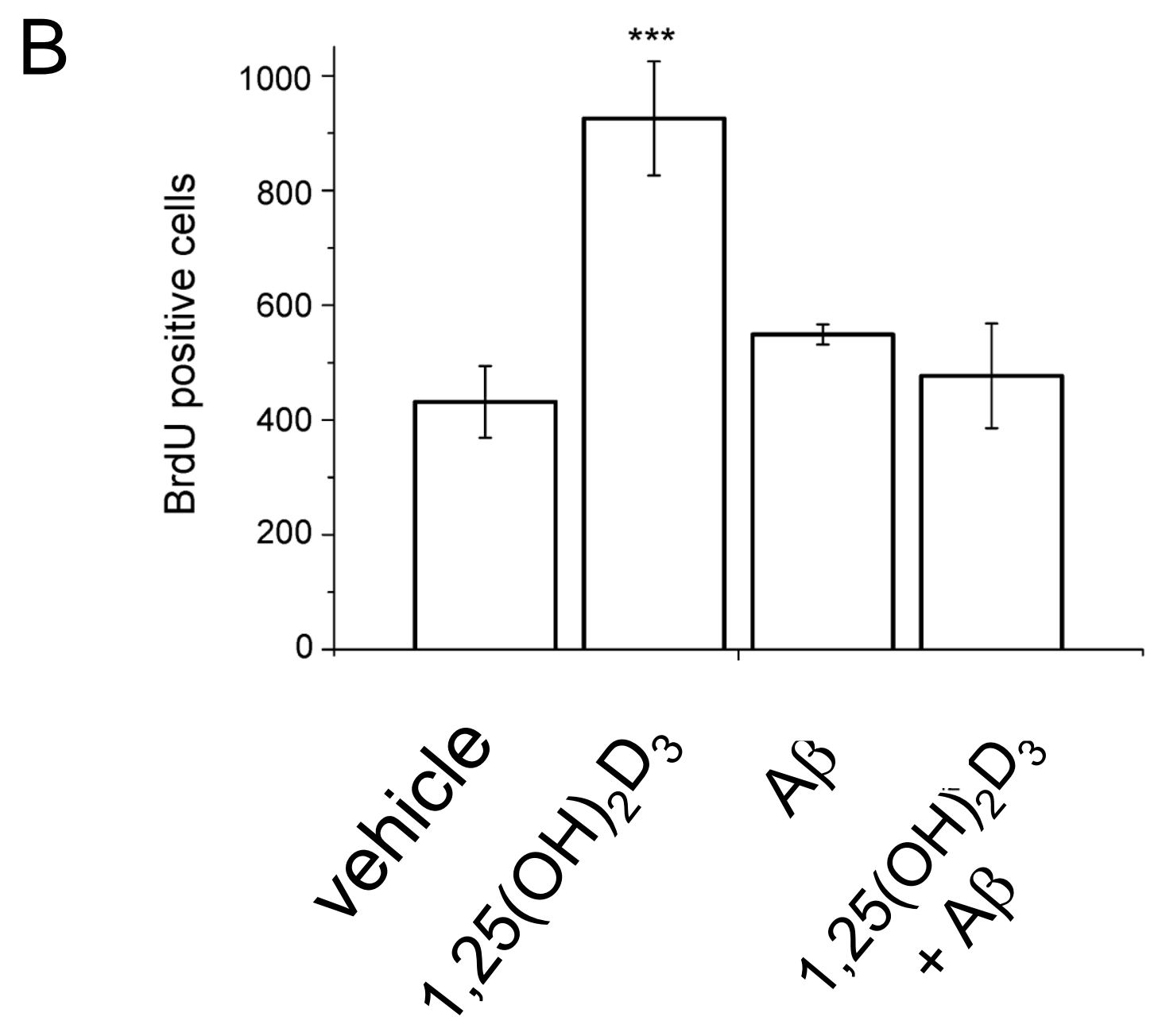

Fig. 3B 


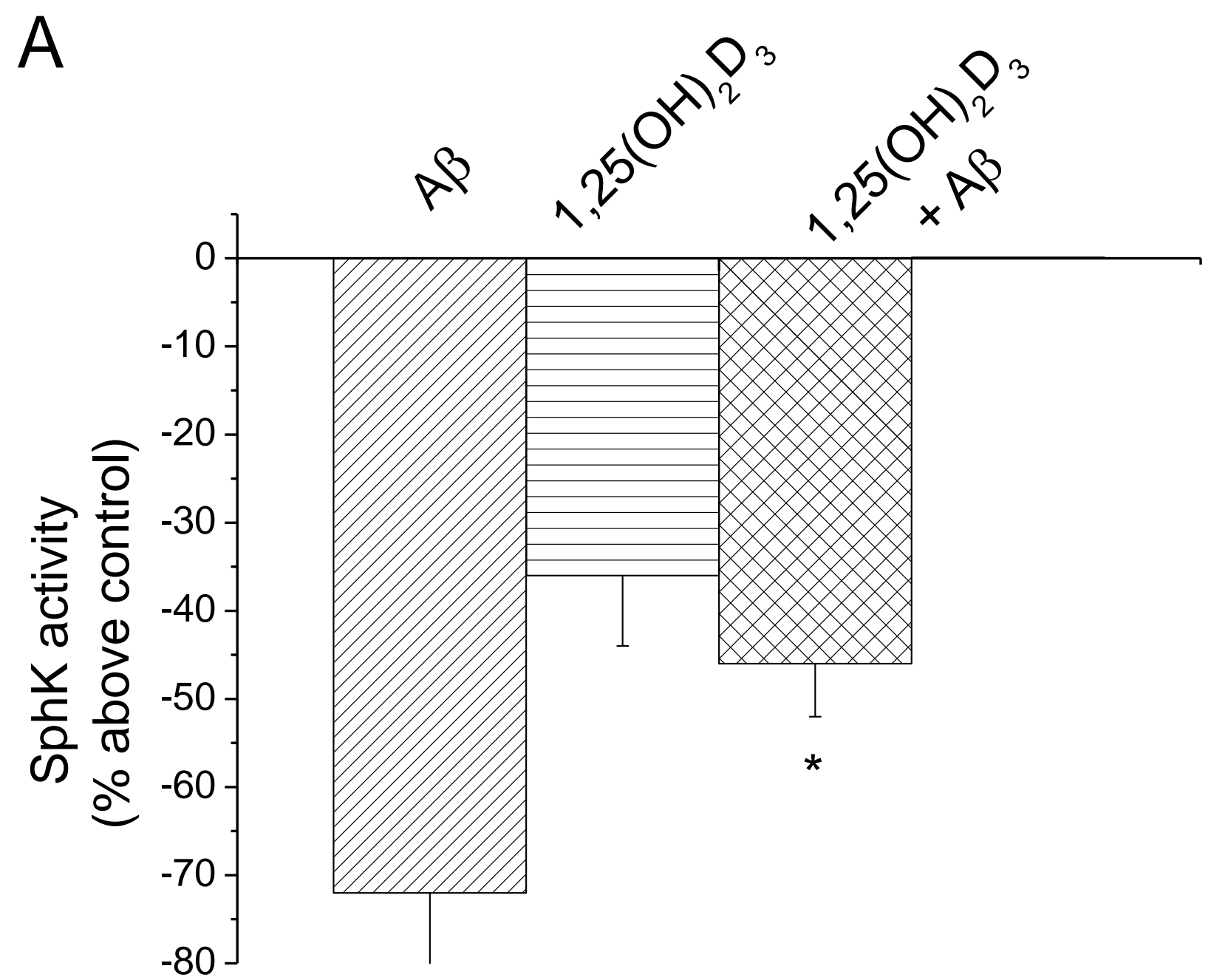

Fig.4A 
B

C
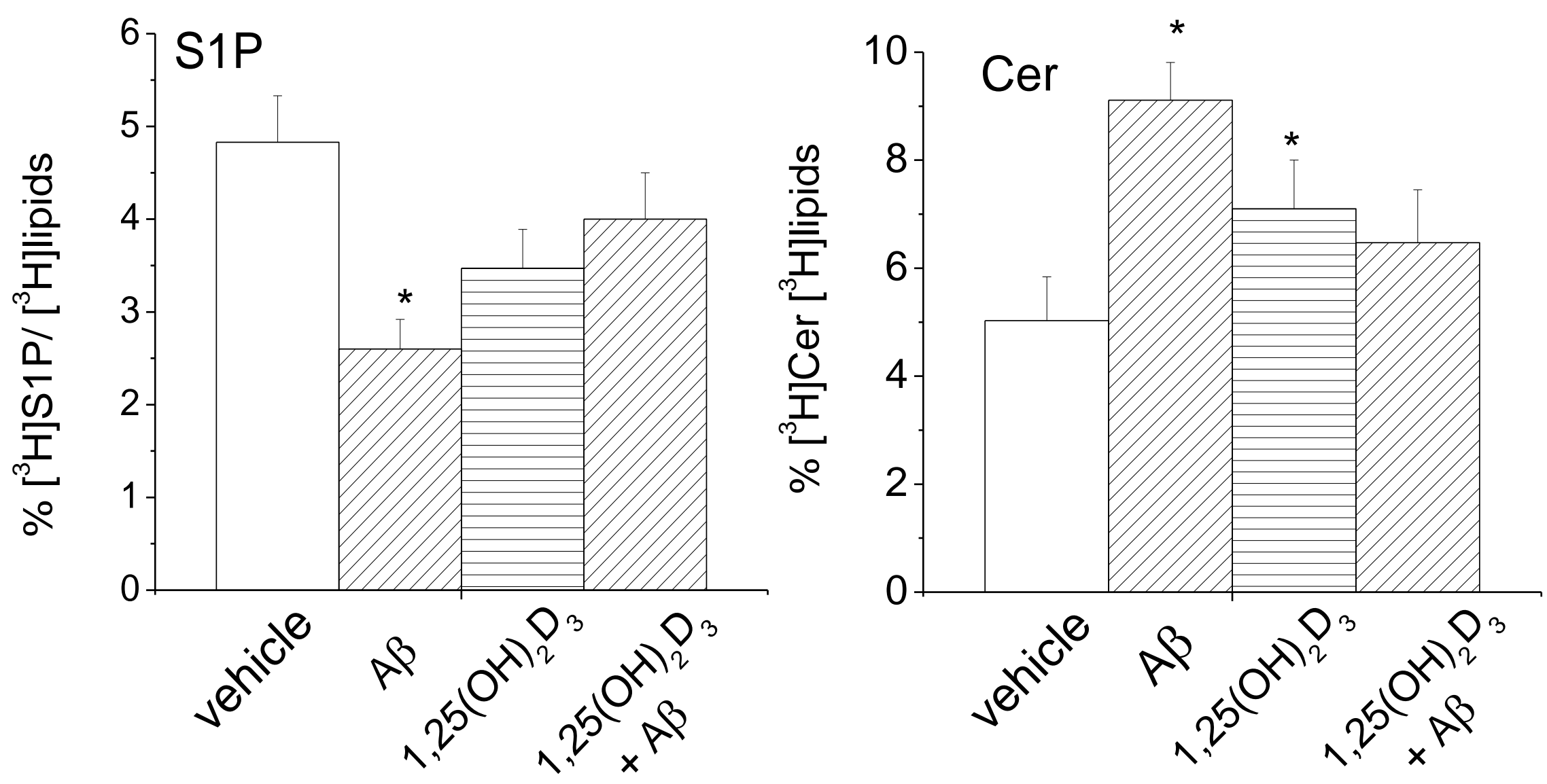

Fig 4BC 
C

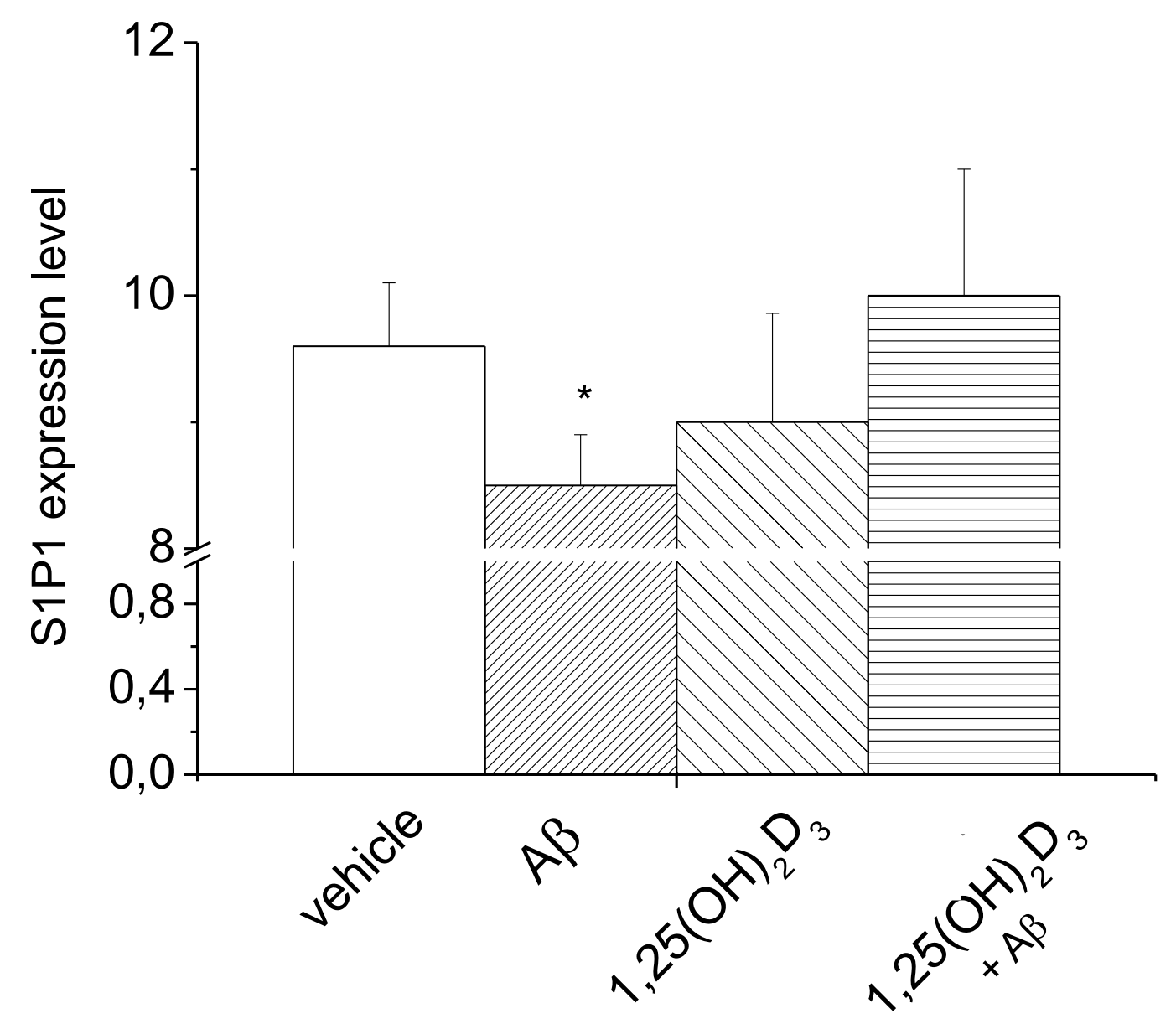

Fig. 5C 

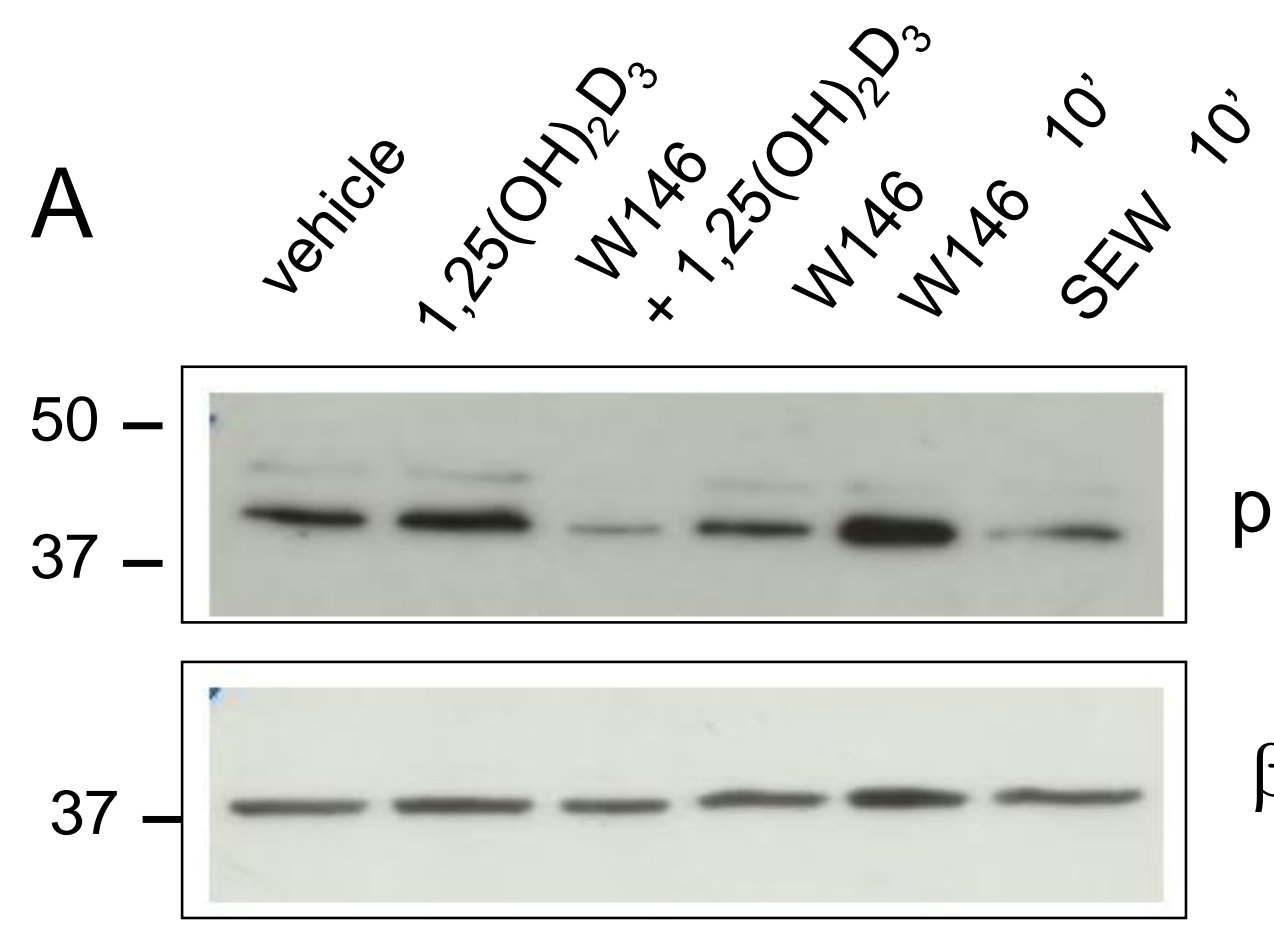

p-p38

$\beta$-actin

Fig. $6 A B$

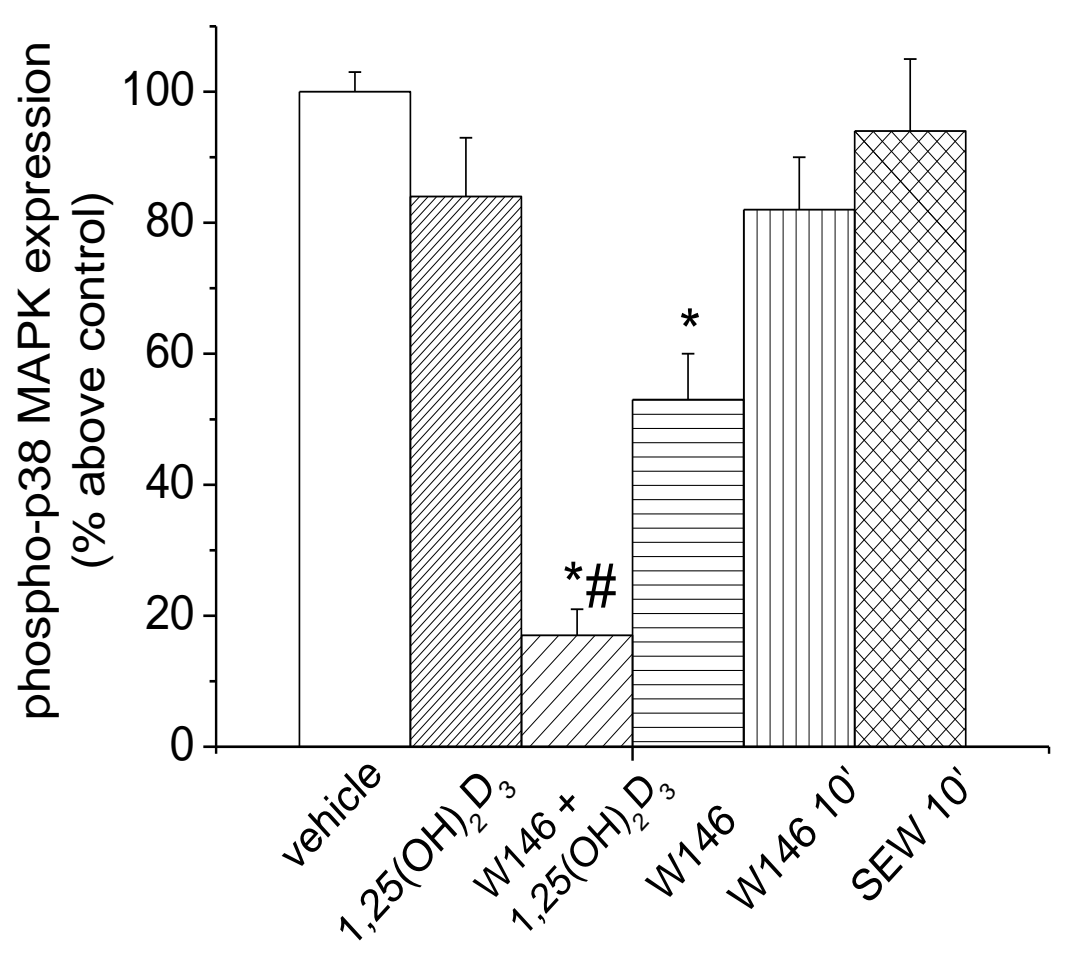


C
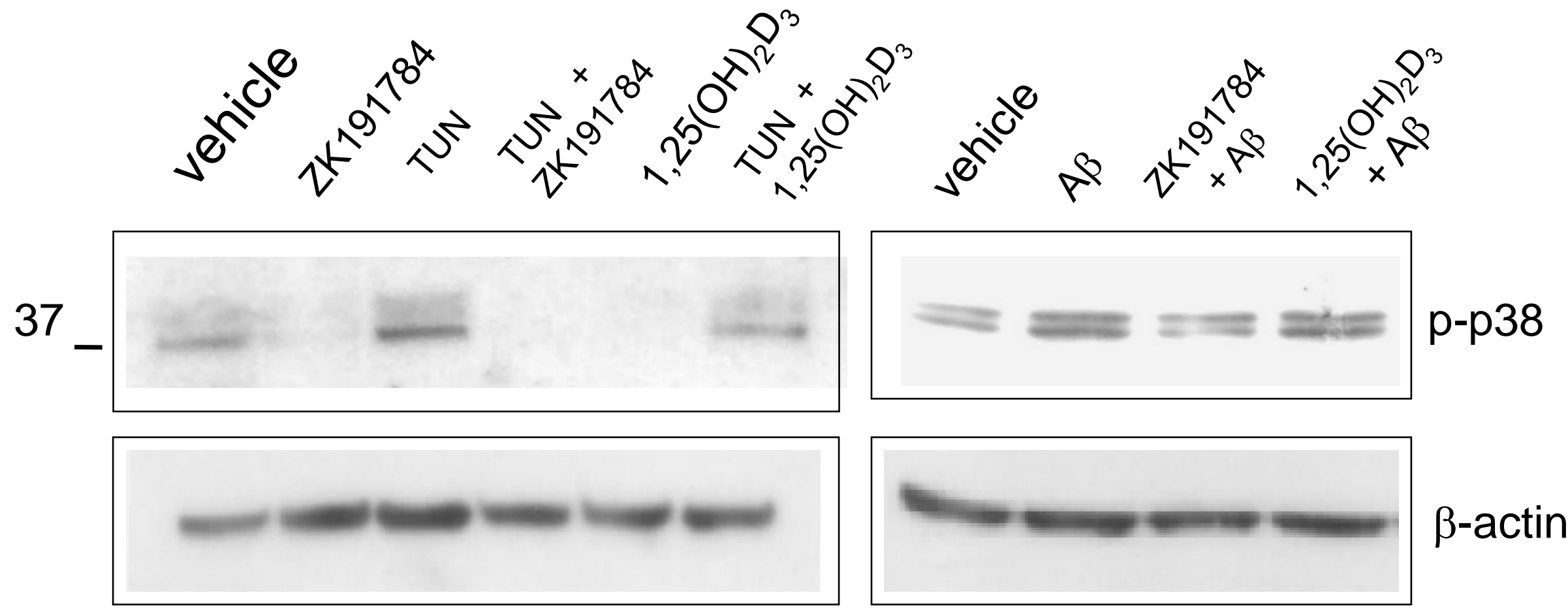

Fig. 6C 

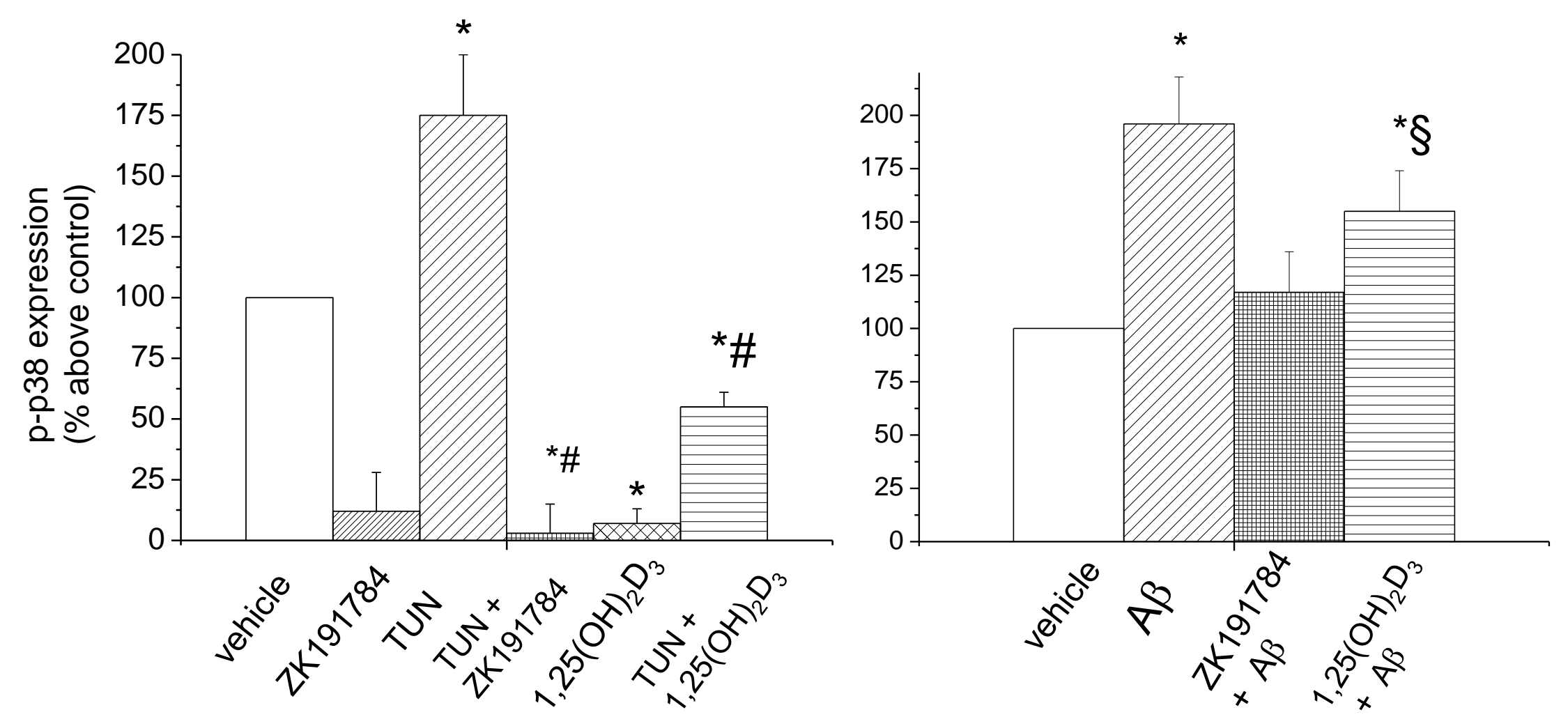

Fig. 6D 
A
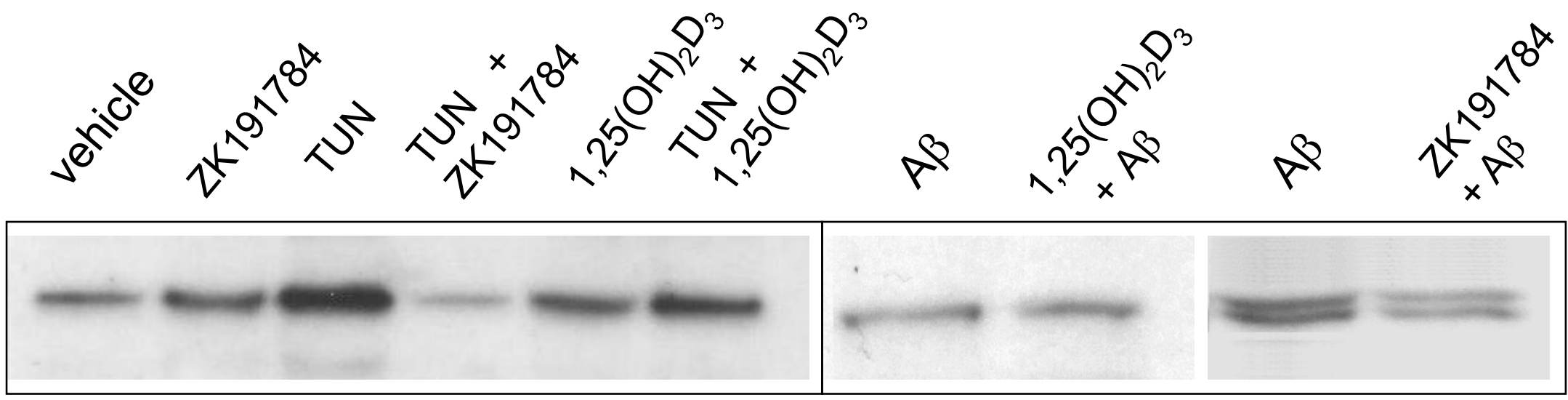

ATF4

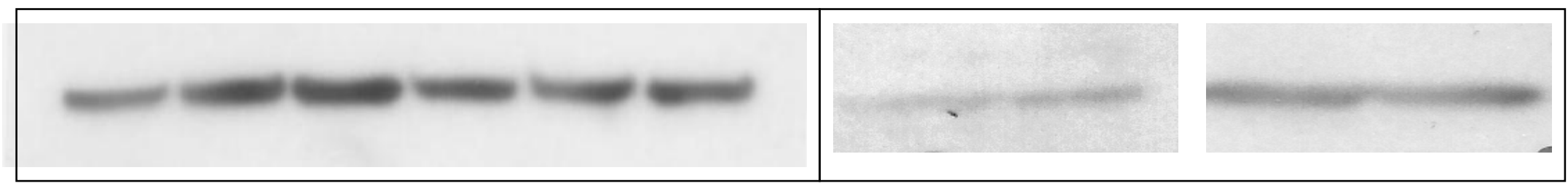

$\beta$-actin

Fig. 7A 